\title{
An old tool for a new generation: Using the Star power simulation to teach social inequality
}

\author{
Barbara Prince
}

Follow this and additional works at: https://researchrepository.wvu.edu/etd

\section{Recommended Citation}

Prince, Barbara, "An old tool for a new generation: Using the Star power simulation to teach social inequality" (2014). Graduate Theses, Dissertations, and Problem Reports. 7340.

https://researchrepository.wvu.edu/etd/7340

This Thesis is protected by copyright and/or related rights. It has been brought to you by the The Research Repository @ WVU with permission from the rights-holder(s). You are free to use this Thesis in any way that is permitted by the copyright and related rights legislation that applies to your use. For other uses you must obtain permission from the rights-holder(s) directly, unless additional rights are indicated by a Creative Commons license in the record and/ or on the work itself. This Thesis has been accepted for inclusion in WVU Graduate Theses, Dissertations, and Problem Reports collection by an authorized administrator of The Research Repository @ WVU. For more information, please contact researchrepository@mail.wvu.edu. 
An Old Tool for a New Generation: Using the Star Power Simulation to Teach Social Inequality

\author{
Barbara Prince \\ Thesis submitted \\ to the College of Arts and Sciences \\ at West Virginia University \\ in partial fulfillment of the requirements for the degree of \\ Master of Arts in \\ Sociology
}

Jennifer Steele, Ph.D., Chair

Amy Hirshman, Ph.D.

Melissa Latimer, Ph.D.

Department of Sociology and Anthropology

\title{
Morgantown, West Virginia
}

2014

Keywords: Star Power, teaching, stratification, inequality

Copyright 2014 Barbara Prince 
All rights reserved

INFORMATION TO ALL USERS

The quality of this reproduction is dependent upon the quality of the copy submitted.

In the unlikely event that the author did not send a complete manuscript and there are missing pages, these will be noted. Also, if material had to be removed, a note will indicate the deletion.

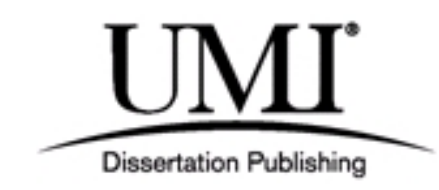

UMI 1554864

Published by ProQuest LLC (2014). Copyright in the Dissertation held by the Author.

Microform Edition () ProQuest LLC.

All rights reserved. This work is protected against unauthorized copying under Title 17, United States Code

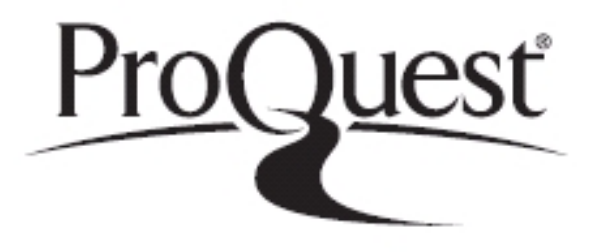

ProQuest LLC.

789 East Eisenhower Parkway

P.O. Box 1346

Ann Arbor, MI 48106 - 1346 


\title{
ABSTRACT \\ An Old Tool for a New Generation: Using the Star Power Simulation to Teach Social Inequality
}

\begin{abstract}
Barbara Prince
Students today are unique. They are the first generation to be "growing up digital" and are distinctly different from their baby boomer parents. As a result, this net generation does not fit well within the passive nature of the standard format of classes. One technique, employed by a growing number of faculty within the field of teaching and learning, to facilitate experiential learning is the use of simulations. One example is the simulation Star Power, which simulates the use/abuse of power, stratification, and inequality. Simulations such as Star Power can be a vital tool for teaching core sociological concepts, including social stratification and social structure by allowing students to actually experience the concepts. More specifically, Star Power provides an opportunity for students to experience social inequality and stratification in a way they may have never experienced it before. While the majority of previous studies on Star Power focus on affective responses to the simulation, this study examined both affective and cognitive responses to Star Power. The data for this study were obtained through the use of survey methodology and qualitative analysis of reflection papers. The sample for this research consisted of all students enrolled in four sections of SO101: Discovering Society at a small comprehensive college in central Pennsylvania during the 2012-2013 Academic Year and 2013 Fall Semester. Students in the course are required to participate in the Star Power simulation and a debriefing session, and then write a 3-5 page reflection paper linking their simulation experiences with class concepts. The sample sizes were 114 (pre-test), 110 (post test), and 126 (reflection papers). Analysis of data revealed 100 percent of students found Star Power worthwhile and all but two recommended it be used in future classes. In addition, six themes were identified through an analysis of reflection papers illustrating the perceived value of the simulation by students. Furthermore, five statistically significant relationships reflected changing views of the importance of coming from a wealthy family, hard work, religion, part of the country and being born a man or a woman after participation in the simulation. The findings of this research will be beneficial to inequality instructors, sociology teachers, and scholars interested in the field of teaching and learning.
\end{abstract}




\section{DEDICATION}

"Have you ever really had a teacher? One who saw you as a raw but precious thing, a jewel that, with wisdom, could be polished to a proud shine?"- Mitch Albom, Tuesdays with Morrie

To the teacher, Michele Lee Kozimor-King Ph.D. This is for you. 


\section{ACKNOWLEDGEMENTS}

Above all I would like to extend my deepest and most sincere gratitude and appreciate to my mentor and friend, Dr. Michele Lee Kozimor-King. Thank you for the idea to do this project and the use of your class, as well as your time, guidance, humor, reiki, and command. Without your support and direction, I never would have made it through. Thank you also for directing me to WVU. Who knew when you simply forwarded me an email saying "Any interest at all?" it would result in my WVU Master's degree. Even after five years I still learn something from you every day and for that I am always grateful. You truly are one of the good ones.

Thank you to my Chair, Dr. Jennifer Steele, for her guidance, inquisitive mind, thorough reviews of multiple drafts of this thesis, and patience over the past year. Your flexibility, humor, and positivity made this process one of a kind. Thank you also for the freedom and support to pursue this research. The past two years have definitely been a learning experience and I am grateful for your time and understanding.

Thank you also to the other members of my committee, Dr. Melissa Latimer and Dr. Amy Hirshman, for their multiple reviews of my thesis and detailed feedback on the meaning of my findings and my writing style. Thank you also for your time and attention over the past year. I know how very busy you are and am very grateful for the time I was able to spend learning from you and working with you.

Next I would like to thank my housemates, Lynnsie Doty and Angela Sycafoose, for their constant support, humor, and motivation. Living with you over the past year has made me appreciate having roommates in a way I never have before. Thanks for always being there to listen when I needed to vent or figure something out and for reading more pieces of this thesis than I'm sure you ever wanted. Thank you also to Karol Kelley for fixing my laptop and providing me with data analysis materials which made the completion of this thesis much easier. The 144 has been the place to be and I'm so grateful I was able to make this journey with all of you.

Also thanks to my friend Mike Shields for his support and outside perspective over the past two years. Writing this thesis wasn't the same without you by my side writing one too, but I am grateful for your feedback and humor more than ever. Our weekly phone calls helped me get through many weeks and you always know how to make me laugh with a text or video. Thanks for being my Draco Malloy.

I would also like to acknowledge my first year advisor, Dr. Lisa Dilks. Thanks for teaching me about t-tests and the culture of academia.

Finally, thanks to my precious cat Fluffs for listening to me talk about Star Power at all hours of the day and night and for being the perfect therapy cat. 


\section{Table of Contents}

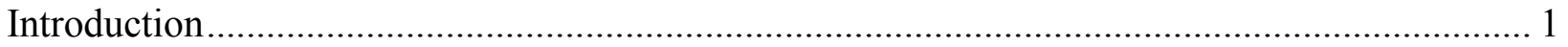

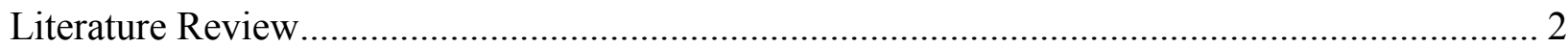

Educating the Net Generation ............................................................................. 2

Simulations/Teaching Inequality and Stratification................................................... 5

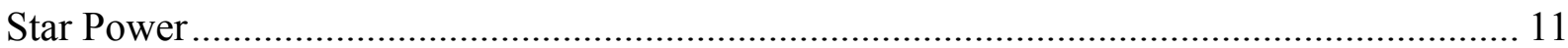

Research Questions and Hypotheses .............................................................................. 14

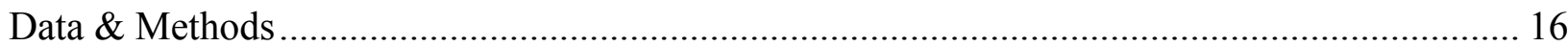

Data

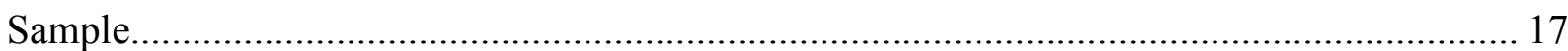

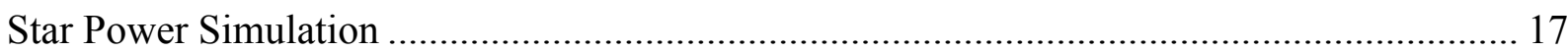

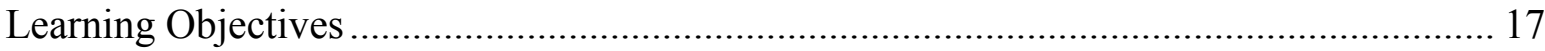

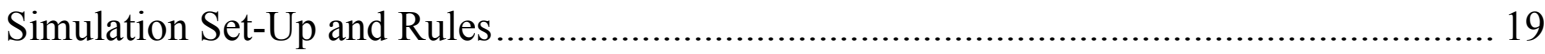

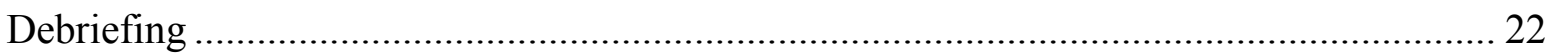

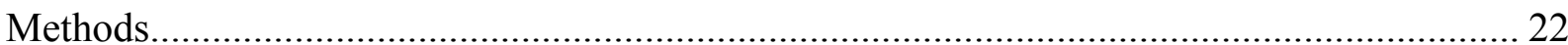

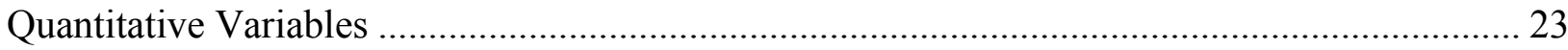

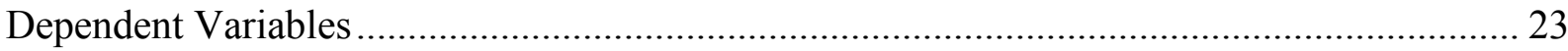

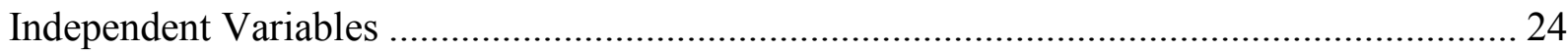

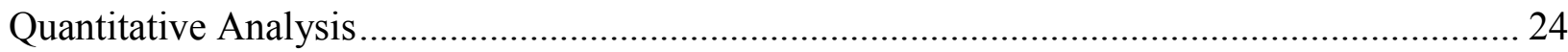

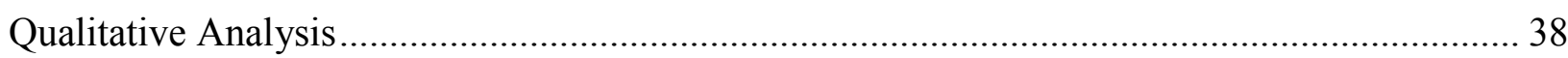

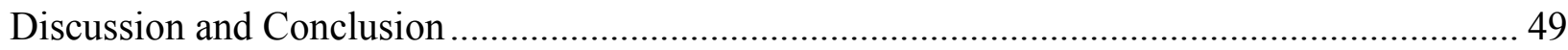

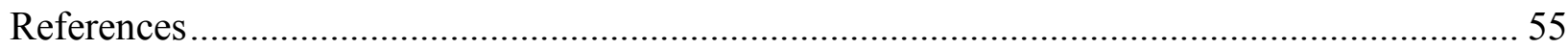

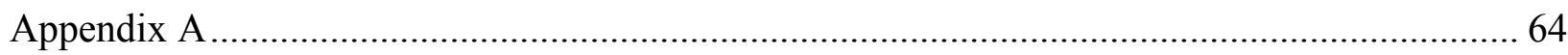

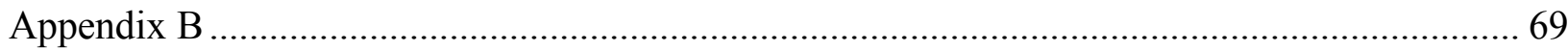

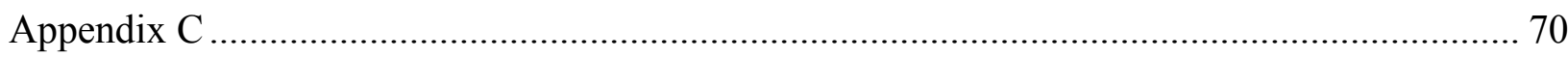

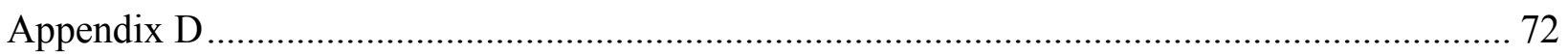




\section{List of Tables and Figures}

Table 1.1: Descriptive Statistics of Key Dependent and Independent Variables ....................... 25

Table 1.2: Descriptive Statistics for Factors Affecting Upward Mobility ................................. 26

Table 2.1: T-Tests for Getting Ahead in Life ....................................................................... 29

Table 2.2: T-Tests for Getting Ahead in Life Pre-Test Data .................................................... 30

Table 2.3: T-Tests for Getting Ahead in Life Post-Test Data................................................ 31

Table 2.4: T-Tests for Getting Ahead in Life (Females Only) ............................................. 32

Table 2.5: T-Tests for Getting Ahead in Life (Males Only) ................................................... 33

Table 2.6: T-Tests for Getting Ahead in Life Pre-Test Data .................................................. 34

Table 2.7: T-Tests for Getting Ahead in Life Post Test Data ................................................... 35

Table 2.8: T-Tests for Getting Ahead in Life (First Years Only) .......................................... 36

Table 2.9: T-Tests for Getting Ahead in Life (Sophomore, Juniors, and Seniors)..................... 37

Figure 1: Word Cloud of all terms identified in reflection papers .......................................... 40 


\section{Introduction}

Undergraduate students today do not fit well within the passive nature of the standard format of most introductory level lecture classes. This generation of students, (born between 1977 and 1997), defined as the net generation or net geners by Tapscott (2009), were the first generation to be "growing up digital." The net geners are beginning to transform every institution of modern life, and education is no exception. They are not content sitting quietly and listening to a lecture; they expect a dialogue and desire choice in their education (Tapscott 2009). According to Mann (2009) almost 60 percent of students find at least half of their lectures boring while nearly 30 percent find most or all of their lectures boring. Additionally, net geners expect their education to be interesting and fun (Tapscott 2009). Tapscott (2009) suggests that for teachers to become more effective in this new digital age they should focus on lifelong learning, lecture less, empower students, and design educational programs around the norms of choice, customization, transparency, integrity, collaboration, fun, speed, and innovation. One technique that incorporates nearly all these norms of the net generation are simulations.

Simulations can be used to illustrate nearly any sociological concept or topic from migration, courtship and family planning to ethnocentrism, the sociological imagination and inequality. Simulation can also be a vital tool in helping instructors overcome obstacles, for instance student rage, paralysis, or resistance associated with teaching difficult concepts (such as stratification and inequality) by allowing students to actually experience such constructs (Davis 1992). One example of a simulation used to illustrate social stratification and inequality is Star Power. Developed by Gary Shirts in 1969, it is a face-to-face real-time simulation used to illustrate inequality and stratification through the use and abuse of power (Simulation Training Systems 2013). Star Power has been experienced by over three million people in over one 
hundred different contexts from business to educational settings (Simulation Training Systems 2013).

Given the importance of stratification and inequality to the discipline of Sociology and the distinctive nature of the net generation, this study will seek to answer four distinct questions: (1) How do students in the net generation perceive the Star Power simulation as a learning tool? (2) What effect does participation in the Star Power simulation have on students' perceptions of structural and individual barriers to equality and mobility? (3) What demographic differences exist in changes in attitudes after participation in the Star Power simulation? (4) Which class concepts do students link to their Star Power experience? This study will also fill previous gaps in the literature by examining subgroup comparisons after participation in the Star Power simulation as well as examining both cognitive and affective responses to the simulation.

\section{Literature Review}

Educating the Net Generation

Previous researchers (Tapscott 2009; Oblinger and Oblinger 2005; Oblinger and Hanger 2005; Hay 2000; Prensky 2006; McNeely 2005; Carlson 2005) have examined educating the net generation. The net generation, as defined by Tapscott (2009), are individuals born between the years of 1977 and 1997. This generation, following Generation X, is known by many other names as well. For example, according to the Carlson (2009) and the U.S. Census Bureau individuals born between 1983 and 2001 are New Boomers, while Collins-Mayo and Mayo (2006) label individuals born after 1980 as Generation Y, and Howe and Strauss (2000) identify individuals born between 1982 and 1999 as Millennials. Regardless of what name is used, this generation is distinctly different from the baby boomer generation for whom the educational system was built and developed (Carlson 2005). 
Consistent with the norms of the net generation identified by Tapscott, other researchers identified key techniques for teaching members of the net generation. Wilson (2004) identified how Chickering and Gamson's (1987) seven principles for good practice in undergraduate education (including student-faculty contact, active learning, prompt feedback, high expectations, cooperation among students, and service-learning) should be modified for the net generation. She explains that many of the net generation have lived sheltered lives with parents who advocated for them, and as a result they will need to learn to advocate for themselves (Wilson 2004). Faculty may have to establish norms of connecting with students. Another example, is making use of the team-oriented nature of students in the net generation. According to Howe and Strauss (2003), most individuals of net generation age grew up working in groups or playing on teams. While this raises concerns of some faculty about the ability of net geners to think independently, Wilson (2004) argues that this could be beneficial because of students' willingness and ability to work with peers to enhance learning.

Net-Geners are also multitaskers. They have grown up habitually using media in many different formats (Barnes et al. 2007). Multitasking is a part of the net geners lifestyle, and thus learning style (Carlson 2005; Oser 2005). The Kaiser Family Foundation (2005) found that net geners cram 8.5 hours of media usage into just 6 hours. However, Glenn (2010) found that while self-described multitaskers are often extremely confident in their abilities, they are actually worse at multitasking than other people. This may pose a problem for educators when dealing with the net generation.

While students in the net generation are very education oriented, they are selective about how and what they want to learn (Carlson 2005; Barnes et al. 2007; Tapscott 2009). These students have grown up with the Internet and instant access to answers; as a result they are 
impatient and expect immediate results (Carlson 2005). Undergraduate students routinely have access to PowerPoint presentations and lecture notes online, so they see little reason to sit through lectures where there will be no participation on their part (Carlson 2005).

Studies have found that the net generation does not fit well within the traditional format of lecture classes (Carlson 2005; Barnes et al. 2007; Tapscott 2009; Oblinger and Hanger 2005). Rather than listen to a lecture the net generation wants to be active participants in their educational experience (Tapscott 1997; Carlson 2005; Hay 2000). Experiential learning allows for students to take control and actually participate in their education. Ben McNeely (2005:44), a net gener himself, states "learning through social interaction is important." Overall, there is a greater desire for active, engaged learning experiences for the net generation than any generation before (Barnes et al. 2007).

Experiential learning, as defined by Lewis and Williams (1994:5) is "learning by doing." During the late 1980s/early 1990s, experiential learning increased exponentially and moved from the periphery to the center of education due to three drastic changes in higher education (Lewis and Williams 1994). First, the conception of learning shifted away from the behaviorist model with students as passive receivers to models that stress the importance of meaning formation. Second, there was an unprecedented increase in the number of adults in higher education, each bringing with them experiences and knowledge to be applied in the classroom. Third, there were new expectations and requirements of educators being held accountable for what their students know and are able to do. The trend of implementing experiential learning has continued into the $21^{\text {st }}$ century academy (Dezure n.d.).

Kolb's (1984: 41) Experiential Learning Theory (ELT) states that experience is the central role in the learning process and defines learning as "the process whereby knowledge is 
created through the transformation of experience. Knowledge results from the combination of grasping and transforming experience." In other words, experience is how knowledge is created and learned.

ELT also places the emphasis on individual experience and how it is shaped by social reality (Vince 1998). Vince (1998) built upon ELT and notes that by itself ELT does not take into account social power relations. Kayes (2002) states that the context of power relations such as social status, gender, and cultural dominance will have an impact on learning across different groups. As a result, it is important to examine differences in changing views of inequality and stratification as a result of participation in Star Power depending on different social groups within the classroom.

\section{Simulations/Teaching Inequality and Stratification}

Previous research (Birnbaum 1982; Dorn 1989; Greenblat 1973; Lean 2006) examined the use of simulations in the classroom. Although there is no agreed upon definition of simulations in higher education, simulation are defined by Coppard and Goodman (1977:4) as “an operating representation of central features of reality.” In comparison, Birnbaum (1982: 5) defines simulation games as:

activities undertaken by players whose actions are constrained by a set of explicit rules particular to that game and by a predetermined end point. The elements of the game constitute a more or less accurate representation or model of some external reality with which players interact by playing roles in much the same way as they would interact with reality itself.

A simulation game is an activity that replicates some aspect of the real world in a controlled setting. The purpose of a simulation is to replicate reality as closely as possible. A review of the simulation literature by Dorn (1989) found that nearly every goal of teaching and learning has been linked to the use of simulation games. The most prominent claim is that the use of 
simulation games will increase students' interest and motivation to learn because simulations require direct involvement, are different from the normal classroom experience, and demand 100 percent participation (Dorn 1989). By actually "living" the experiences, students increase motivation and interest compared to simply reading about or discussing the concepts (Dorn 1989; Bruin 1985; Davis 1992). While in the past, research on simulations has been contradictory and inconclusive (Greenblat 1973; Dorn 1989; Boocock and Coleman 1966), the American Sociological Association's taskforce on the undergraduate major of sociology stated that "departments should encourage diverse pedagogies including active learning experiences that develop student engagement in the discipline... such as simulations (Grauerholz and Gibson 2006: 19).

The American Sociological Association have also identified stratification and inequality as central concepts to the field of Sociology. By the 1990s, 100 percent of introduction to sociology textbooks included information pertaining to class stratification (up from only $63 \%$ in the 1940s), 95 percent included race stratification and gender stratification (up from $63 \%$ and $0 \%$ in the 1940s respectively) and 79 percent contained information about age stratification (compared to only 6\% in the 1940s) (Kieth and Ender 2004). Furthermore, Persell, Pfeiffer, and Syed (2008: 112) found through interviews with American Sociological Association Presidents and award winning teachers and scholars in the field that the "centrality of inequality" was one of the top five major themes that they hoped students in sociology would understand. However, stratification and inequality are often the most difficult concepts to convey, especially to undergraduate students. As Eells (1987: 73) explains, “[undergraduates] unshakable fervent belief is that everyone can succeed and improve their social class if they just try enough." This is not surprising given the dominant ideology of individualism in the United States (Brislen and 
Peoples 2005; Huber and Form 1973). The challenge for sociology instructors is then to find ways to challenge this ideology and ensure undergraduate students leave with a greater understanding and appreciation for how social structure shapes and maintains social stratification (Brislen and Peoples 2005).

The net generation have distinctly different views than any other generation, but finding ways to effectively teach concepts of stratification and inequality remain just as important. According to Leyden, Teixeria, and Greenberg (2007: 8) this generation "shows deep concern for today's income inequalities and social stratification, and it is possible that looking out for everyone may emerge as their mission." The vast majority of individuals between 18-26 years old $(84 \%)$ reported that the gap between the rich and the poor had grown in the last 20 years and 94 percent reported that the change in the gap between the rich and the poor was a bad thing (Leyden, Teixeria, and Greenberg 2007). Interestingly, the Magid Associates (2006) also found that individuals aged 18-22 were the most likely to support government action to reduce economic differences among Americans. This is unique, however, because individuals in the net generation overall are less interested in politics and less trusting of the government than any of the generations preceding them when they were young (Ng, Lyons, and Schweitzer 2012).

Furthermore, the net generation is quite optimistic when it comes to the future. According to the Pew Research Center (2006), 45 percent of 18-29 year olds believed today's children would grow up better than people are now (more than any other age group). They also believed, more than any other age group, that they would move ahead on a "ladder of life" in the next 5 years (Pew Research Center 2007). Part of this may stem from their personality of individualism and motivation. For instance, high school students in the 2000s were more likely than those in the 1970s to anticipate they would be "very good" at their job in the future and were more likely 
to anticipate attending graduate school or working at a high-status professional job (Ng, Lyons, and Schweitzer 2012: 4-5; Reynolds et al. 2006; Twenge and Campbell 2001).

The net generation is also the most progressive generation and "certainly don't perceive differences between genders, races, or sexual preferences the way other generations do" (Leyden, Teixeria, and Greenberg 2007: 8). More than any other generation, net geners support allowing gays and lesbians to marry and adopt children (Gallop Polls 2011; Pew Research Center 2007). Additionally, the net generation is more accepting of gender equality ( $\mathrm{Ng}$, Lyons, and Schweitzer 2012; Koenig et al. 2011; Thorton and Young-Demargo 2001; Twenge 1997). Net geners expressed the highest support for women's equal role in business, government, and industry, with 88 percent reporting some level of support for women's equal role outside of the home (National Election Survey 2004 as cited in Leyden, Teixeria, and Greenberg 2007). Finally, when it comes to race, this generation largely perceives race as "no big deal" and attitudes overall are seen as extremely progressive (Leyden, Teixeria, and Greenberg 2007: 5; $\mathrm{Ng}$, Lyons, and Schweitzer 2012). For example, 89 percent of net geners reported that they agreed it was alright for blacks and white to date each other compared to only 56 percent of Gen Xers that agreed with the statement (Leyden, Teixeria, and Greenberg 2007: 8; Pew Research Center 2003). However, despite these more progressive attitudes, instructors still face challenges in conveying the impact of structural barriers and lessons of inequality to students in the net generation (Dundes and Harlow 2005; Brislen and Peoples 2005; Sweet and Baker 2011).

Given this challenge, many studies have examined the use of different activities and simulations to teach inequality and stratification (Abelev et al. 2008; Berkowitz, Manohar, and Tinkler 2010; Brezina 1996; Brislen and Peoples 2005; Coghlan and Huggins 2004; Davis 1992; Garoutte and Bobbitt-Zeher 2011; Harlow 2009; Irby-Shasanmi, Oberlin and Saunders 2012; 
McCammon 1999; Nichols, Berry, and Kalogrides 2004; Sweet and Baker 2011; Touzard 2009). The specific simulations assessed throughout the literature vary widely and include Bittersweet Candy, Vanishing Dollar, The Bottom Line, modified Monopoly and Star Power, among others. Overall, findings indicate positive responses and increase in the understanding of concepts related to inequality and stratification (Abelev et al. 2008; Berkowitz, Manohar, and Tinkler 2010; Brezina 1996; Brislen and Peoples 2005; Coghlan and Huggins 2004; Davis 1992; Garoutte and Bobbitt-Zeher 2011; Harlow 2009; Irby-Shasanmi, Oberlin and Saunders 2012; McCammon 1999; Nichols, Berry, and Kalogrides 2004; Sweet and Baker 2011; Touzard 2009). Both Abelev et al. (2008) and McCammon (1999) found that extensive budgeting exercises based on income disparities helped to facilitate the conceptualization of social inequality and stratification. They also found, through a post project survey, that the majority of the students indicated that the budgeting exercises influenced their idea of concepts such as the "American dream" and "equal opportunity" and minimized resistance to the discussion of stratification (Abelev et eal. 2008; McCammon 1999).

Harlow (2009) and Brezina (1996) both used simulations to demonstrate the nature of structural inequality. Harlow (2009) developed two exercises, The Vanishing Dollar and Bittersweet Candy, to demonstrate racial and class inequality. She found that after participating in the exercises, students were more likely to report a "very good" understanding of the concepts surrounding institutional discrimination. Similarly, Brezina's (1996) exercise involves students detailing what American society would look like if all Americans suddenly had the drive and ability to achieve success no matter what. He found that "greater social equality" is never one of the possibilities mentioned by undergraduate students thus demonstrating that inequality is a “built-in feature" of modern society (Brezina 1996). Both Brezina (1996) and Harlow (2009) 
conclude that the exercises are successful in conveying the concepts and nature of structural inequality.

The inequality simulation literature lacks an examination of which specific subpopulations benefit most from the simulation experience (see Abelev et al. 2008; Berkowitz, Manohar, and Tinkler 2010; Brezina 1996; Brislen and Peoples 2005; Coghlan and Huggins 2004; Davis 1992; Garoutte and Bobbitt-Zeher 2011; Harlow 2009; McCammon 1999; Nichols, Berry, and Kalogrides 2004; Sweet and Baker 2011; Touzard 2009). Only Irby-Shasami, Oberlin and Saunders (2012) analyzed outcomes according to different demographic characteristics. In their study of on stratification in healthcare, they found significant differences in attitudes about access to healthcare by gender, race, and SES, which disappeared in the post-test results. IrbyShasami, Oberlin and Saunders (2012) cite the literature on internalized oppression which states that "subordinate groups subconsciously internalize their lower position in the social hierarchy and thus may not point out outside factors that keep them in subordinate positions" (Essed 1992 and Fegagin and Skies 1994 cited in Irby-Shasami, Oberlin and Saunders 2012:131). They argue that the pre-test results reveal the more typical American ideology of individualism and through the simulation the variance in attitudes is minimized across groups (Irby-Shasami, Oberlin and Saunders 2012). So, the change in attitudes shows that the simulation may be successful in shifting students' views, regardless of demographic characteristics, toward a sociological imagination with more of a connection between the individual and society (Irby-Shasami, Oberlin and Saunders 2012).

Alexander Astin's theory of student involvement (developed in 1984) can also be used as a framework to explain learning difference among students at different class standings. Astin's theory suggests that student learning and personal development associated with any educational 
program is directly proportional to the quality and quantity of student involvement in that program (Astin 1999). Thus it would be expected that upperclassmen would show a greater understanding of concepts and shift in attitudes than first year students.

Star Power

One of the most popular simulations used for illustrating stratification and inequality is Star Power. In the game, participants are divided into a three-tiered society in which wealth is distributed unevenly. The groups are marked with square, triangle, and circle pins with the squares being the top group and the circles being the bottom group. Once the society is established, the group with the most wealth makes the rules for the game (Dorn 1989).

Numerous researchers (Allen 2008; Carranza 1974; Dukes 1986; Dukes and Waller 1976; Dundes and Harlow; 2005; Humphrey 1970; Jackson 1979; Nikkel 1976) have examined the use of Star Power. Several trends have emerged when examining the actual simulation. First, the group in power always makes rules that protect their own power while stopping all other groups from advancing (Allen 2008; Carranza 1974; Dukes 1986; Dukes and Waller 1976; Dundes and Harlow; 2005; Humphrey 1970). Dundes and Harlow (2005) report that in the more than 20 times they have conducted the simulation, the squares (the group in power) always structure the game in their favor. Second, the lower groups (triangles and circles) typically pretend to follow the rules while actually defying them (Allen 2008; Dundes and Harlow 2005; Humphrey 1970). Finally, it is common for the simulation to result in hostility and anger among the groups (Carranza 1974; Dundes and Harlow 2005; Humphrey 1970). These common occurrences allow for discussion of privilege versus merit, arbitrary rulemaking in society, maintaining the system in society, status symbols, and the possibility of inequality leading to surrender or rebellion (Carranza 1974; Dundes and Harlow 2005; Humphrey 1970). As Nikkel (1976: 101) put it, 
the game leads to a rich return of useful material which can center around the nature of class, the permanence of inequality, the occurrences of mobility and revolution, the participation of the middle class in radical revolution, and means of disenfranchising lower classes and minorities.

More importantly, Star Power provides an opportunity for students to experience social inequality and stratification in a way they may have never experienced it before (Davis 1992). Often, students are sorted differently than they are in larger society. For example, a female student may end up in the top group and given the power to exploit males in the lower groups. It is incredibly rare that students do not take advantage of this opportunity (Davis 1992).

Overall, studies have found that Star Power is enjoyed and viewed seen as beneficial by participants (Allen 2008; Carranza 1974; Dundes and Harlow; 2005; Humphrey 1970; Tamminga 1977). Allen (2008) found that 100 percent of respondents found Star Power to be an educational activity and 100 percent recommended that it be used again by the instructor in the future. This is similar to a study by Carranza (1974), who found that 100 percent of participants believed that some useful knowledge about the generation of conflict can be obtained from Star Power. Furthermore, Humphrey (1970), found that 88 percent of participants said the game was worthwhile and 94 percent reported they enjoyed playing the game. Several studies (Allen 2008; Corbeil 2011; Tamminga 1977) have used Star Power in a modified format to teach concepts such as history, management, leadership, and moral education. Even when not being used for its intended purpose, researchers have found that the majority of students report Star Power as a useful activity (Allen 2008; Corbeil 2011; Tamminga 1977). Overall, students enjoy the simulation and are provided with an experience that provokes emotions and feelings that will not be forgotten (Allen 2008).

Similarly, Jackson (1979) found that undergraduate students, in general, voiced very positive opinions about participation in the Star Power simulation. However, results from a 
quasi-experimental design, involving a treatment group (who played Star Power), a Hawthorne Group (who played an alternate simulation- Bafa Bafa), and a comparison group who participated in neither simulation found that only 4 of the 26 predicted hypotheses were supported and "the conclusion is inescapable that these particular runs of these games had very little- certainly less than expected- effect on students on the attitudes, cognitions, and affects measured" (Jackson 1979: 133). As Jackson (1979: 133) put it, these findings stand in sharp contrast to the impressionistic evidence reported by all concerned with the students partaking of the two simulations. These reporters- both assistants in the simulation runs and teachers of the students- were besieged with favorable reactions from students during, immediately after, and well after the simulation sessions. This impressionistic evidence parallels that found throughout the literature, ranging from unprompted declarations of approval of the simulation exercise at the time, to self-initiated references to aspects of the simulation experience in subsequent class discussions, to attempts to build on aspects of the simulation experience in later class work by individual students.

Despite these findings, Jackson (1979: 134) encouraged future research to utilize other measures in order to capture "the transition of the pleasure taken in simulations into educational benefits."

This research builds upon the existing literature in five important ways. First, this study updates the literature by examining the effectiveness of the Star Power simulation for teaching core sociological concepts, including social stratification, social structure, and socioeconomic status, in an introductory sociology course populated by the net generation. While the majority of previous studies focused on affective responses to the simulation, this study examined both affective and cognitive responses to Star Power. Second, this study updates the literature by examining the perceived value of the Star Power simulation by the net generation. While two studies (Allen 2008 and Dundes and Harlow 2005) have examined the net generation and Star Power Allen (2008) examined the use of Star Power in a modified format to teach history and Dundes and Harlow (2005) utilized only observations and reports on course evaluations to 
measure the effectiveness of Star Power. Third, using quantitative methodology, this research examines the effects of gender and class standing (first years, sophomores, etc.) on changes in students' views of inequality following participation in the simulation. Only one study (Jackson 1979) examined Star Power using a pre-post test comparison. Dundes and Harlow (2005:42) suggested that future research should use pre-post test in conjunction with the simulation so that instructors could "assess the extent to which students can connect classroom activities to real life." Fourth, this study examines which introductory sociology concepts undergraduate students' link with the Star Power experience. Fifth, this study fills a gap in the literature by utilizing a mixed methods approach to examine effectiveness and perceived value of the Star Power simulation.

\section{Research Questions and Hypotheses}

$\mathrm{RQ}_{1}$ : How do students in the Net Generation perceive the Star Power simulation as a learning tool?

Previous research by Allen (2008), Carranza (1974), Dukes (1986), Dukes and Waller (1976), Dundes and Harlow ( 2005), Humphrey (1970), Jackson (1979), and Nikkel (1976), discussed above, have found Star Power is enjoyed and seen as beneficial by participants. Furthermore, simulations, such as Star Power, incorporate the eight norms of the Net Generation, as cited by Tapscott (2009), educators need to use to be effective is this new digital age. Thus, it is expected that students will perceive Star Power as a valuable learning tool and recommend it for future use.

$\mathrm{RQ}_{2}$; What effect, if any, will participation in the Star Power simulation have on students' perceptions of structural and individual barriers to equality and mobility?

Previous research by Brislen and Peoples (2005) and Irby-Shasanmi, Oberlin and Saunders (2012), among others discussed above, has found that the dominant ideology among 
Americans is of individualism. In particular, students new to sociology tend to minimize or are less likely to attribute much structural or macro level factors, instead emphasizing the impact of micro- or individual-level features on outcomes (Irby-Shasanmi, Oberlin and Saunders 2012:131). Additionally, while students from the net generation have more progressive views toward equality than previous generations (Leyden, Teixeria, and Greenberg 2007; Ng, Lyons, and Schweitzer 2012), it is unclear if this translates to a greater understanding and awareness of structural barriers to equality and mobility. Previous research by Abelev et al.( 2008), Berkowitz, Manohar, and Tinkler 2010), Brezina (1996), Brislen and Peoples (2005), Coghlan and Huggins (2004), Davis (1992), Garoutte and Bobbitt-Zeher (2011), Harlow (2009), Irby-Shasanmi, Oberlin and Saunders (2012), McCammon (1999), Nichols, Berry, and Kalogrides (2004), Sweet and Baker (2011), Touzard (2009),discussed above, has found that incorporating activities and simulations that challenge students' individualism to be effective in ensuring that students leave with an understanding of how social structures shape and maintain stratification. Thus, it is expected that students will show a shift in attitudes toward more recognition of structural factors as essential to equality and mobility after participation in the Star Power simulation.

$\mathrm{RQ}_{3}$ : What demographic differences exist, if any, in changes in attitudes after participation in the Star Power simulation?

$\mathrm{H}_{1}$ : Females will have a greater change in attitudes following the Star Power simulation than males.

Rationale: The literature on internalized oppression has found that subordinate groups internalize their lower position in the social hierarchy and may not point to outside factors that keep them there (Essed 1992; Fegin and Sikes 1994). As a result, students from subordinate groups may be more likely to initially attribute inequality and stratification to individual characteristics than social forces even 
when it does not match their lived experiences. However, Irby-Shasanmi, Oberlin and Saunders (2012) found that students from these subordinate groups show the largest change in attitudes following participation in a simulation.

$\mathrm{H}_{2}$ : Sophomores, Juniors, and Seniors will have a greater change in attitudes following the Star Power simulation than First-Years.

Rationale: Astin's theory of student involvement states that students learn more the more involved they are with the college experience (Astin 1999). Thus it is expected that upperclassmen will be more likely to gain a greater understanding, resulting in a larger shift in attitudes toward structural level barriers than first year students.

RQ4: Which introductory sociology class concepts do participants link to their Star Power experience?

Star Power is meant to illustrate social inequality and stratification through the use and abuse of power (Simulation Training Systems 2013). Thus, it is expected that students will chose concepts from the stratification unit of the course to link to their Star Power experience. However, students are not limited to which class concepts they can choose. If students are able to successfully link terms from outside the stratification and inequality chapter it is possible that the simulation could be used for to teach concepts other than stratification and inequality.

\section{Data \& Methods}

\section{Data}

The data for this research were obtained through the use of survey methodology and analysis of reflection papers. The questionnaires consisted of closed-ended questions modified from the Social Inequality Module of the General Social Survey (GSS). The GSS is a nationally representative survey conducted biennially by the National Opinion Research Center (NORC) at 
the University of Chicago (Smith, Marsden, Hout and Kim 2013). The assignment instructions for the reflection paper is presented in Appendix B.

\section{Sample}

The sample for this research consisted of all students enrolled in SO101: Discovering Society at Elizabethtown College during the 2012 Fall Semester, 2013 Spring Semester and 2013 Fall Semesters. Elizabethtown College is a private comprehensive college located in south central Pennsylvania with approximately 1,900 undergraduate students. Students enrolled in SO101 are required to participate in the Star Power simulation and debriefing as part of the course.

Demographically, the student body at Elizabethtown College is majority female (65\%), white (88\%) and in-state (69\%) (CollegeBoard 2013). Discovering Society is listed as a Social Science core course and is required of several majors at Elizabethtown College ${ }^{1}$. One section of SO101: Discovering Society was offered during the 2013 Spring semester and 2013 Fall semester, while two sections were offered during the 2012 Fall semester. The same instructor taught all four sections of SO101: Discovering Society. The average class size for all four sections was 29 students. Given that the simulation is designed for 18 to 35 players (Shirts 1993; Dundes and Harlow 2005), the class size and small college setting was ideal.

\section{Star Power Simulation}

Learning Objectives

Star Power was developed by Gary Shirts in 1969 for Simulation Training Systems and according to Shirts (1993: 3),

\footnotetext{
${ }^{1}$ Discovering Society is one of ten options to fulfill the Social Science Core requirement and is required for all Biology-Pre Med, Social Work, and Sociology/Anthropology majors.
} 
[Star Power] is a game in which a low-mobility, three-tiered society is built through the distribution of wealth in the form of chips. Once established, the group with the most wealth is given the power to make the rules for the game. Almost without exception, they make rule which secure their position of power. The other groups generally consider these rules unfair and often label them "dictatorial", "fascist", or "racist". Sometimes there is open revolt against the Squares, other times the Circles and Triangles give up and drop out. When the frustration and conflict reaches a certain level, the director ends the game. The experience is then analyzed and discussed.

According to Simulation Training Systems (2013), Star Power teaches:

1. Each of us may be more vulnerable to the temptation to abuse power than we realize. Power can be amazingly seductive.

2. To change behavior, it may be necessary to change the system in which that behavior occurs.

3. Few people are likely to participate in an endeavor if they feel powerless.

4. If rules do not have legitimacy, they will not be obeyed.

5. What seems fair to those in power is not likely to seem fair to those who are out of power.

6. Persons who are promoted rarely remember those they leave behind.

7. Power is like fire, it can be used to help make the world a better place to live or it can be terribly destructive.

8. In any system, there needs to be checks on power. If there are no checks, power will almost certainly be abused.

In addition, the following learning outcomes have been established in congruence with the Star

Power simulation (Wessex Simulations n.d.):

Star Power helps participants to:

- See and feel the effect of disempowerment.

- Understand that power must have a legitimate basis to be effective.

- Realize that sharing power can increase it while hoarding or abusing power can diminish it.

- Understanding the effect that systems can have on power.

- Be aware of how tempting it is for well-intentioned people to abuse power.

- Understanding that there are different kinds of power.

- Personally experience and discuss the excitement of power and the despair of powerlessness.

- Understand that what seems fair to those in power, is not likely to seem fair to those who are out of power.

- Consider that people who are promoted rarely seem to remember those they leave behind.

Star Power has been experienced by over three million people and has been used in a variety of

settings ranging from educational to business. (Simulation Training Systems 2013). 


\section{Simulation Set-Up and Rules}

Before students arrive, the room is arranged in circles, with chairs in three approximately equal sized groups. Next the trading rules, scoring chart, and bonus round rules (all explained below) are posted on the board. Finally, three columns with the headings $0-17,18-19$, and 20+ are put on the board.

When students arrive they are told to sit anywhere and that the groups have no meaning. Then each participant draws five chips from a bag and is told not to look at them. Once everyone arrives and has settled in the rules are explained. The students are told that they will be participating in a trading game and that the person with the most points at the end of the game will be the winner ${ }^{2}$. The trading rules are then explained as follows: "1. Players must clasp hands to make a trade. 2. Only the best five chips count. 3. Chips of unequal value must be traded once hands are clasped. 4. No trading or talking unless hands are clasped. 5. If arms are folded, you do not have to trade. 6. All chips are to be hidden at all times." (Shirts 1993: 8). Students are also told that each trading round will last approximately 5 minutes and once the round is over they are to put their score and initials in the appropriate column on the board.

Next the scoring chart (see below) is explained. The facilitator points out to the participants that while obviously gold is the most valuable chip color, there are bonus points associated with having multiple red, white, or blue chips. For example, if you have five blue chips, you receive 11 bonus points. The students are then shown six chips, four reds and two blues, and asked what the score for that hand would be (15). This is to make sure students understand that you can only count the best five chips in your hand (even if you have more). After the scoring is explained students are told they can look at the chips they have and calculate

\footnotetext{
${ }^{2}$ The official rules say to announce that the top three individuals will be the winners.
} 
their starting score. Then, after answering any questions, the facilitator tells students to begin their first trading session.

After 5-10 minutes, the facilitator tells students that the first trading round is over and to write their score and initials on the board in the appropriate column. Next, the facilitator designates which group each person now belongs to by drawing a circle, triangle, or square next to the score and initials. The top third of the class are squares, the middle third triangles, and the bottom third circles. ${ }^{3}$ Students are then told to change seats to be with the other members of their group, and each participant is given a pin with their shape on it (square, triangle, or circle).

\begin{tabular}{|l|c|c|c|c|c|}
\hline \multicolumn{7}{|c|}{ Scoring } \\
\hline & \multicolumn{5}{|c|}{ Number of Chips: } \\
\hline Gold & $\mathbf{1}$ & $\mathbf{2}$ & $\mathbf{3}$ & $\mathbf{4}$ & $\mathbf{5}$ \\
\hline Green & 8 & 15 & 24 & 32 & 40 \\
\hline Red & 4 & 8 & 12 & 16 & 20 \\
& 3 & 6 & 9 & 12 & 15 \\
& & & & $\frac{+2}{14}$ & $\frac{+3}{18}$ \\
\hline White & 2 & 4 & 6 & 8 & 10 \\
& & & & $\frac{+5}{13}$ & $\frac{+7}{17}$ \\
\hline Blue & 1 & 2 & 3 & 4 & 5 \\
& & & & $\frac{+8}{12}$ & +11 \\
\hline
\end{tabular}

(Chart adapted from Star Power Director's Instructions (Shirts 1993: 6)

Once students are in their new groups with pins, the bonus round rules are explained as follows: "1. Each bonus chip is worth 3 points. 2 . Bonus chips distributed by unanimous vote...3. Persons may be expelled from group by majority vote. 4. Undistributed bonus chips return to the director." (Shirts 1993: 11). They are also told that the bonus round will last five

\footnotetext{
${ }^{3}$ In the official rules, the bottom group is the triangles and the middle group is the circles.

${ }^{4}$ The official rules say that only 1,2 , or 3 persons in the group can get bonus chips, but this instructor plays that as many people in the group as possible can receive bonus points, but they must be full points (i.e. no half points, etc.).
} 
minutes and all bonus points received will stay with them throughout the entire game, regardless of the chips in their hand. Students are then given 5 minutes to complete the bonus round.

After the bonus round is complete, each participant is allowed to choose another chip from a bag. Unlike in the beginning of the game when all the bags had an equal distribution of chips, the squares get to choose from a bag enriched with gold and green chips, while the circles must choose from a bag with mainly white and blue chips. Once everyone has a new chip, another trading round is conducted. Students are allowed to trade with anyone following the same rules as the first trading round. At the completion of the round, participants put their new scores (including bonus points) on the board and are divided into three groups again. Any promotions/demotions occur (including switching of seats and pins) and then another bonus round is conducted.

The same sequence is repeated (bonus round, picking new chips ${ }^{5}$, trading round, promotions/demotions) several times until either little to no movement between groups is occurring or any of the groups seem particularly rowdy or upset. Once this happens, it is announced that "Since the Squares have worked so hard and are playing the game the best, they now get to make the rules for the game." Paper and pencils are then given to the other groups because they are allowed to suggest rules, in writing, which the squares can then accept, reject, or modify.

The Squares are given complete control and the remainder of the game is played by ear. Some encouragement or ideas may be given to the Circles or Triangles on how to move one of

\footnotetext{
${ }^{5}$ When larger groups participate in the simulation, it is common to run out of chips. When this happens either the squares get to pick first, then the triangles, and then whatever is left is given to some of the circles or the circles are asked to put back one chip each into the square's bag so that the squares can pick an additional chip. It should be noted that typically the squares do not even notice that not everyone got to pick a new chip or that the circles have to give back a chip. Often, rather, they complain about the low value of the remaining or available chips.
} 
their own up to the top group or on how to get around the new rules implemented by the Squares. Once the rules have become so restrictive that it is impossible for any mobility to occur the simulation is ended and the debriefing takes place.

\section{Debriefing}

Debriefing is an essential part of any simulation process (Dorn 1989). After the completion of the simulation, a debriefing takes place to aid participants in connecting their experience to other experiences. According to Shirts (1993: 17), “Generally, however, groups need to talk about the game in personal terms of "who did what to whom" before going on to the issues involved." After the general discussion of "who did what to whom" students discuss what the simulation represents in real-life and other examples of where the behaviors experienced in the game can be seen. The debriefing process typically lasts about 30 minutes.

\section{Methods}

Star Power is used as a precursor to the Stratification and Inequality unit, and occurs approximately three quarters of the way through the semester. It is the second simulation used in the course with the first being Barnga, a simulation about culture. The remainder of the course is predominately lecture and discussion based. The Star Power simulation and debriefing lasts approximately two hours and is held outside of the regularly scheduled class time ${ }^{6}$. Following completion of the simulation, students are required to write a 3-5 page reflection paper linking the simulation experience with introductory sociology concepts (see Appendix B). This paper accounts for 12 percent of the course grade. The students were given the pre-test survey during the first week of class. They were then given the post-test survey the class period after the

\footnotetext{
${ }^{6}$ The simulation was held at the following dates/times: November 8, 2012 9:00-11:00PM, November 9, 2012 2:004:00PM, March 25, 2013 9:30-11:30PM, March 26, 3013 3:30-5:30PM, November 21, 2013 9:30-11:30PM and November 22, 2013 2:00-4:00PM.
} 
simulation occurs. The pre and post test data are not paired. As sated above, previous research on Star Power by Dundes and Harlow (2005: 42) suggests using a pre-post test in conjunction with the simulation so that instructors could "assess the extent to which students can connect classroom activities to real life." Results of the survey were analyzed.

An analysis of section B of the reflection papers was also conducted. Reflection papers were analyzed and coded for the following criteria: (1) Which class concepts are students most frequently identifying in connection with the simulation? (2) What is their overall perception of Star Power as a learning tool? (3) Would they recommend the simulation be used again? Why or why not? A sample of 55 papers were examined for themes by two independent reviews. After meeting and discussing the themes and codes, the remainder of the papers were coded. The major themes and trends are reported. The assignment instructions for Part B of the paper are as follows,

Analyze what you have learned from the simulation. In your analysis, identify and define at least 3 different class concepts (from social interaction, social structure, deviance, stratification, inequality, poverty, discrimination, etc.) that you can relate to the simulation experience. You may use any class concept from social interaction through the last day of class. After defining the concept, give concrete and specific examples of how the simulation illustrated the concept. Finally, discuss what you thought about the simulation as a learning tool. What did you personally learn about social interaction, social structure, deviance, social power, inequality, status symbols, status, roles, and inequality? Do you recommend that I use Star Power next semester? Please give examples of why or why not. Again, please give specific examples to support your opinion. If completed with sufficient detail, this section should take you at least 2 pages.

\section{Quantitative Variables}

Dependent Variables

The first dependent variable for this research was attitudes toward inequality and social stratification. These concepts were operationalized using modified questions from the Social Inequality Module of the General Social Survey (See Appendix A for full questionnaire). 
Examples of these questions include: On a scale from 1 to 5, with 1 being 'not important at all' and 5 being 'essential' rate how important you think each of the following is for getting ahead in life: coming from a wealthy family, having well educated parents, being born a man or a woman, and having a good education yourself.

The second dependent variable for this research was perceived value of the Star Power simulation. This was operationalized using the following question:

How worthwhile do you think Star Power was?

Very Worthwhile

Somewhat Worthwhile

A Little Worthwhile

Not at All Worthwhile

\section{Independent Variables}

The first independent variable for this research was gender. Gender was operationalized using the following question:

Gender:

Male

Female

The second independent variable for this research was class standing. Class standing was operationalized using the following question:

Class Standing:

First-Year

Sophomore

Junior

Senior

\section{Quantitative Analysis}

Table 1.1 provides descriptive statistics for the entire sample. The total sample size after deleting missing cases was 114 for the pre-test and 110 for the post test. The majority, 63.6 percent, of the sample was female. This is consistent with the demographic composition of the 
institution where the study was conducted. Not surprisingly, 37.3 percent of the sample was first years and 40.9 percent were sophomores. This was to be expected since the study was conducted in a one hundred level, introductory class.

\section{Table 1.1: Descriptive Statistics of Key Dependent and Independent Variables}

\begin{tabular}{|c|c|c|c|c|}
\hline & \multicolumn{2}{|c|}{$\begin{array}{c}\begin{array}{c}\text { Pre-Test } \\
\mathrm{N}=114\end{array} \\
\text {. }\end{array}$} & \multicolumn{2}{|c|}{$\begin{array}{c}\text { Pre-Test } \\
\mathrm{N}=110\end{array}$} \\
\hline & $\mathbf{N}$ & $\%$ & $\mathbf{N}$ & $\%$ \\
\hline $\begin{array}{l}\text { How worthwhile do you think Star Power was? } \\
\text { Not At All Worthwhile }\end{array}$ & & & 0 & 0.0 \\
\hline A Little Worthwhile & & & 5 & 4.5 \\
\hline Somewhat Worthwhile & & & 36 & 32.7 \\
\hline Very Worthwhile & & & 69 & 62.7 \\
\hline \multicolumn{5}{|l|}{ Gender } \\
\hline Female & 41 & 36.0 & 70 & 63.6 \\
\hline Male & 18 & 15.8 & 40 & 36.4 \\
\hline Not Asked & 55 & 48.2 & 0 & 0.0 \\
\hline \multicolumn{5}{|l|}{ Class Standing } \\
\hline First Year & 23 & 20.2 & 41 & 37.3 \\
\hline Sophomore & 22 & 19.3 & 45 & 40.9 \\
\hline Junior & 9 & 7.9 & 16 & 14.5 \\
\hline Senior & 5 & 4.4 & 8 & 7.3 \\
\hline Not Asked & 55 & 48.2 & 0 & 0.0 \\
\hline
\end{tabular}

Consistent with previous research (Allen 2008; Dundes and Harlow; 2005; Humphrey 1970; Tamminga 1977) one hundred percent of respondents found Star Power to be worthwhile. With the majority of respondents, 62.7 percent, saying they thought that Star Power was very worthwhile. In other words, Star Power was still found to be perceived as an effective and worthwhile teaching tool for sociological concepts by the net generation. Results of cross tabulations (see Appendix C) revealed no statistical or substantive differences by class standing, gender, or shape (group in the simulation) when starting and finishing the simulation when examining perceived worthwhileness of the simulation. 


\begin{tabular}{|c|c|c|c|c|c|}
\hline \multicolumn{6}{|c|}{ Table 1.2: Descriptive Statistics for Factors Affecting Upward Mobility } \\
\hline \multirow[t]{2}{*}{$\begin{array}{l}\text { How important do you think each of the } \\
\text { following is for getting ahead in life? }\end{array}$} & \multicolumn{2}{|c|}{$\begin{array}{c}\text { Pre-Test } \\
\text { N=114 }\end{array}$} & \multicolumn{2}{|c|}{$\begin{array}{c}\text { Post-Test } \\
\mathrm{N}=110\end{array}$} & \multirow[t]{2}{*}{$\begin{array}{c}\text { Percent } \\
\text { Difference }\end{array}$} \\
\hline & $\mathbf{N}$ & $\%$ & $\mathbf{N}$ & $\%$ & \\
\hline \multicolumn{6}{|l|}{ Coming from a Wealth Family } \\
\hline Essential & 1 & 0.9 & 6 & 5.5 & 4.6 \\
\hline Very Important & 15 & 13.2 & 30 & 27.3 & 14.1 \\
\hline Fairly Important & 47 & 41.2 & 48 & 43.6 & 2.4 \\
\hline Not Very Important & 43 & 37.7 & 23 & 20.9 & -16.8 \\
\hline Not Important at All & 8 & 7.0 & 3 & 2.7 & -4.3 \\
\hline \multicolumn{6}{|l|}{ Having Well Educated Parents } \\
\hline Essential & 5 & 4.4 & 10 & 9.1 & 4.7 \\
\hline Very Important & 35 & 30.7 & 37 & 33.6 & 2.9 \\
\hline Fairly Important & 57 & 50.0 & 51 & 46.4 & -3.6 \\
\hline Not Very Important & 14 & 12.3 & 9 & 8.2 & -4.1 \\
\hline Not Important at All & 3 & 2.6 & 3 & 2.7 & 0.1 \\
\hline \multicolumn{6}{|l|}{ Having a Good Education Yourself } \\
\hline Essential & 53 & 46.5 & 53 & 48.2 & 1.7 \\
\hline Very Important & 53 & 46.5 & 47 & 42.7 & -3.8 \\
\hline Fairly Important & 8 & 7.0 & 8 & 7.3 & 0.3 \\
\hline Not Very Important & 0 & 0.0 & 2 & 1.8 & 1.8 \\
\hline Not Important at All & 0 & 0.0 & 0 & 0.0 & 0.0 \\
\hline \multicolumn{6}{|l|}{ Ambition } \\
\hline Essential & 72 & 63.2 & 67 & 60.9 & -2.3 \\
\hline Very Important & 37 & 32.5 & 31 & 28.2 & -4.3 \\
\hline Fairly Important & 5 & 4.4 & 12 & 10.9 & 6.5 \\
\hline Not Very Important & 0 & 0.0 & 0 & 0.0 & 0.0 \\
\hline Not Important at All & 0 & 0.0 & 0 & 0.0 & 0.0 \\
\hline \multicolumn{6}{|l|}{ Hard Work } \\
\hline Essential & 83 & 72.8 & 71 & 64.5 & -8.3 \\
\hline Very Important & 28 & 24.6 & 27 & 24.5 & 0.1 \\
\hline Fairly Important & 3 & 2.6 & 9 & 8.2 & 5.6 \\
\hline Not Very Important & 0 & 0.0 & 1 & 0.9 & 0.9 \\
\hline Not Important at All & 0 & 0.0 & 2 & 1.8 & 1.8 \\
\hline \multicolumn{6}{|l|}{ Natural Ability } \\
\hline Essential & 7 & 6.1 & 14 & 12.7 & 6.6 \\
\hline Very Important & 30 & 26.3 & 38 & 34.5 & 8.2 \\
\hline Fairly Important & 69 & 60.5 & 48 & 43.6 & -17.3 \\
\hline Not Very Important & 8 & 7.0 & 9 & 8.2 & 1.2 \\
\hline Not Important at All & 0 & 0.0 & 1 & 0.9 & 0.9 \\
\hline
\end{tabular}




\begin{tabular}{|c|c|c|c|c|c|}
\hline \multicolumn{6}{|c|}{ Table 1.2 (continued): Descriptive Statistics for Factors Affecting Upward Mobility } \\
\hline \multirow[t]{2}{*}{$\begin{array}{l}\text { How important do you think each of the } \\
\text { following is for getting ahead in life? }\end{array}$} & \multicolumn{2}{|c|}{$\begin{array}{l}\text { Pre-Test } \\
\mathrm{N}=114\end{array}$} & \multicolumn{2}{|c|}{$\begin{array}{l}\text { Post-Test } \\
\mathbf{N}=110\end{array}$} & \multirow[t]{2}{*}{$\begin{array}{c}\text { Percent } \\
\text { Difference }\end{array}$} \\
\hline & $\mathbf{N}$ & $\%$ & $\mathbf{N}$ & $\%$ & \\
\hline \multicolumn{6}{|l|}{ Knowing the Right People } \\
\hline Essential & 12 & 10.5 & 17 & 15.5 & 5.0 \\
\hline Very Important & 38 & 33.3 & 38 & 34.5 & 1.2 \\
\hline Fairly Important & 48 & 42.1 & 47 & 42.7 & 0.6 \\
\hline Not Very Important & 16 & 14.0 & 6 & 5.5 & -8.5 \\
\hline Not Important at All & 0 & 0.0 & 2 & 1.8 & 1.8 \\
\hline \multicolumn{6}{|l|}{ A Person’s Race } \\
\hline Essential & 1 & 0.9 & 3 & 2.7 & 1.8 \\
\hline Very Important & 5 & 4.4 & 13 & 11.8 & 7.4 \\
\hline Fairly Important & 31 & 27.2 & 27 & 24.5 & -2.7 \\
\hline Not Very Important & 40 & 35.1 & 35 & 31.8 & -3.3 \\
\hline Not Important at All & 37 & 32.5 & 32 & 29.1 & -3.4 \\
\hline \multicolumn{6}{|l|}{ Having Political Connections } \\
\hline Essential & 3 & 2.6 & 3 & 2.7 & 0.1 \\
\hline Very Important & 9 & 7.9 & 15 & 13.6 & 5.7 \\
\hline Fairly Important & 35 & 30.7 & 43 & 39.1 & 8.4 \\
\hline Not Very Important & 59 & 51.8 & 37 & 33.6 & -18.2 \\
\hline Not Important at All & 8 & 7.0 & 12 & 10.9 & 3.9 \\
\hline \multicolumn{6}{|l|}{ A Person's Religion } \\
\hline Essential & 3 & 2.6 & 2 & 1.8 & -0.8 \\
\hline Very Important & 0 & 0.0 & 5 & 4.5 & 4.5 \\
\hline Fairly Important & 11 & 9.6 & 16 & 14.5 & 4.9 \\
\hline Not Very Important & 49 & 43.0 & 51 & 46.4 & 3.4 \\
\hline Not Important at All & 51 & 44.7 & 36 & 32.7 & -12.0 \\
\hline \multicolumn{6}{|l|}{ The Part of a Country a Person Comes From } \\
\hline Essential & 0 & 0.0 & 0 & 0.0 & 0.0 \\
\hline Very Important & 4 & 3.5 & 9 & 8.2 & 4.7 \\
\hline Fairly Important & 22 & 19.3 & 33 & 30.0 & 10.7 \\
\hline Not Very Important & 49 & 43.0 & 44 & 40.0 & -3.0 \\
\hline Not Important at All & 39 & 34.2 & 24 & 21.8 & -12.4 \\
\hline \multicolumn{6}{|l|}{ Being Born a Man or a Woman } \\
\hline Essential & 0 & 0.0 & 1 & 0.9 & 0.9 \\
\hline Very Important & 9 & 7.9 & 21 & 19.1 & 11.2 \\
\hline Fairly Important & 25 & 21.9 & 34 & 30.9 & 9.0 \\
\hline Not Very Important & 51 & 44.7 & 28 & 25.5 & -19.2 \\
\hline Not Important at All & 29 & 25.4 & 26 & 23.6 & 0.9 \\
\hline \multicolumn{6}{|l|}{ Political Beliefs } \\
\hline Essential & 0 & 0.0 & 1 & 0.9 & 0.9 \\
\hline Very Important & 4 & 3.5 & 8 & 7.3 & 3.8 \\
\hline Fairly Important & 22 & 19.3 & 25 & 22.7 & 3.4 \\
\hline Not Very Important & 53 & 46.5 & 47 & 42.7 & -3.8 \\
\hline Not Important at All & 35 & 30.7 & 29 & 26.4 & -4.3 \\
\hline
\end{tabular}


Table 1.2 shows attitudes toward factors affecting upward mobility. Respondents perceive structural level factors, such as coming from a wealthy family, parental education, race, religion, gender, and region as less important for getting ahead in life than individual level factors such as having ambition, and hard work. For instance, on the pre-test, hard work was seen as the most important factor for getting ahead in life, with 72.8 percent of the sample reporting that hard work was 'essential' followed by ambition (with 63.2 percent reporting this was essential).

Importantly, respondents did report higher levels of importance for structural factors on the post-test than the pre-test. There was 14.1 percent difference in reported "coming from a wealthy family" as very important between the pre-test and post test. There was also an 11.2 percent difference in reporting "being born a man or a woman" as very important between the pre and post test. Consistent with previous research (Abelev et al. 2008; Berkowitz, Manohar, and Tinkler 2010; Brezina 1996; Brislen and Peoples 2005; Coghlan and Huggins 2004; Davis 1992; Garoutte and Bobbitt-Zeher 2011; Harlow 2009; Irby-Shasanmi, Oberlin and Saunders 2012; McCammon 1999; Nichols, Berry, and Kalogrides 2004; Sweet and Baker 2011;Touzard 2009), students showed a shift in attitudes towards more recognition of structural factors, such as being born a man or woman, as more essential to mobility after participation in the Star Power simulation. However, it should be noted that although a shift does occur, the individual level factors of hard work and ambition were still seen as the most important factors for getting ahead in life on the post test, but with an 8.3 percent and 2.3 percent decrease from the pre-test.

Table 2.1 shows the $t$-test results for the entire sample of factors affecting upward mobility by test. There were statistically significant negative differences between the pre and post-tests with regard to structural level factors of coming from a wealthy family $(t=-4.21$; 


\begin{tabular}{|c|c|c|c|c|c|}
\hline \multicolumn{6}{|c|}{ Table 2.1: T-Tests for Getting Ahead in Life } \\
\hline \multirow{2}{*}{$\begin{array}{l}\text { How important do you think each of } \\
\text { the following is for getting ahead in } \\
\text { life? }\end{array}$} & \multicolumn{2}{|c|}{$\begin{array}{c}\text { Pre-Test } \\
\mathrm{N}=114\end{array}$} & \multicolumn{2}{|c|}{$\begin{array}{c}\text { Post Test } \\
\mathrm{N}=\mathbf{1 1 0}\end{array}$} & \multirow[t]{2}{*}{ t-test } \\
\hline & Mean & SD & Mean & SD & \\
\hline Coming from a Wealthy Family & 2.63 & 0.83 & 3.12 & 0.90 & $-4.21 * * *$ \\
\hline Having Well Educated Parents & 3.22 & 0.82 & 3.38 & 0.87 & -1.44 \\
\hline Having a Good Education Yourself & 4.39 & 0.62 & 4.37 & 0.70 & 0.25 \\
\hline Ambition & 4.59 & 0.58 & 4.50 & 0.69 & 1.03 \\
\hline Natural Ability & 3.32 & 0.70 & 3.50 & 0.85 & -1.77 \\
\hline Hard Work & 4.70 & 0.51 & 4.49 & 0.83 & $2.27 *$ \\
\hline Knowing the Right People & 3.40 & 0.86 & 3.56 & 0.88 & -1.38 \\
\hline Political Connections & 2.47 & 0.84 & 2.63 & 0.95 & -1.36 \\
\hline Race & 2.06 & 0.92 & 2.27 & 1.09 & -1.56 \\
\hline Religion & 1.73 & 0.84 & 1.96 & 0.91 & $-2.01 *$ \\
\hline Part of the Country & 1.92 & 0.82 & 2.25 & 0.89 & $-2.84 * *$ \\
\hline Being Born a Man or a Woman & 2.12 & 0.88 & 2.48 & 1.08 & $-2.72 * *$ \\
\hline Political Beliefs & 1.96 & 0.80 & 2.14 & 0.92 & -1.56 \\
\hline
\end{tabular}

Note: Scales range from $1=$ Not At All Important to $5=$ Essential

* Significant at the .05 level

** Significant at the .01 level

$* * *$ Significant at the .001 level

$\mathrm{p}<.001)$, religion $(t=-2.01 ; \mathrm{p}<.05)$, part of the country an individual is from $(t=-2.84 ; \mathrm{p}<.01)$, and being born a man or a woman $(t=-2.72 ; \mathrm{p}<.01)$. In other words, students reported higher levels of importance for these characteristics for getting ahead in life after participating in Star Power.

There was also a statistically significant positive difference between the pre and post tests with regard to the individual level factor of hard work $(t=2.27 ; \mathrm{p}<.05)$. In other words, students reported lower levels of importance for hard work in getting ahead in life after participating in 
Star Power. These findings are consistent with previous research (Abelev et al. 2008; Berkowitz, Manohar, and Tinkler 2010; Brezina 1996; Brislen and Peoples 2005; Coghlan and Huggins 2004; Davis 1992; Garoutte and Bobbitt-Zeher 2011; Harlow 2009; Irby-Shasanmi, Oberlin and Saunders 2012; McCammon 1999; Nichols, Berry, and Kalogrides 2004; Sweet and Baker 2011; Touzard 2009) who found that students begin to recognize structural factors more after participating in simulations and activities.

\begin{tabular}{lcc|cc|c}
\hline \multicolumn{7}{c}{ Table 2.2: T-Tests for Getting Ahead in Life Pre-Test Data } \\
\hline $\begin{array}{l}\text { How important do you think each of } \\
\text { the following is for getting ahead in }\end{array}$ & $\begin{array}{c}\text { Females } \\
\text { N=41 }\end{array}$ & \multicolumn{2}{c}{$\begin{array}{c}\text { Males } \\
\text { N=18 }\end{array}$} & t-test \\
life? & Mean & SD & Mean & SD & \\
\hline Coming from a Wealthy Family & 2.73 & 0.90 & 2.78 & 0.88 & -0.01 \\
Having Well Educated Parents & 3.27 & 0.74 & 3.56 & 0.51 & -0.15 \\
Having a Good Education Yourself & 4.39 & 0.70 & 4.33 & 0.49 & 0.36 \\
Ambition & 4.51 & 0.64 & 4.67 & 0.49 & -0.92 \\
Natural Ability & 3.32 & 0.72 & 3.28 & 0.67 & 0.20 \\
Hard Work & 4.68 & 0.57 & 4.56 & 0.62 & 0.77 \\
Knowing the Right People & 3.39 & 0.83 & 3.50 & 0.92 & -0.45 \\
Political Connections & 2.54 & 0.87 & 2.78 & 0.81 & -1.00 \\
Race & 2.10 & 1.02 & 2.50 & 0.71 & -1.52 \\
Religion & 1.68 & 0.73 & 2.00 & 1.24 & -1.33 \\
Part of the Country & 2.00 & 0.74 & 2.22 & 0.88 & -1.00 \\
Being Born a Man or a Woman & 2.15 & 0.88 & 2.39 & 0.92 & -0.96 \\
\hline
\end{tabular}

Note: Scales range from $1=$ Not At All Important to $5=$ Essential

* Significant at the .05 level 


\begin{tabular}{|c|c|c|c|c|c|}
\hline \multicolumn{6}{|c|}{ Table 2.3: T-Tests for Getting Ahead in Life Post-Test Data } \\
\hline \multirow{2}{*}{$\begin{array}{l}\text { How important do you think each } \\
\text { of the following is for getting } \\
\text { ahead in life? }\end{array}$} & \multicolumn{2}{|c|}{$\begin{array}{c}\text { Females } \\
\mathbf{N}=70\end{array}$} & \multicolumn{2}{|c|}{$\begin{array}{l}\text { Males } \\
\mathbf{N}=40\end{array}$} & \multirow[t]{2}{*}{ t-test } \\
\hline & Mean & SD & Mean & SD & \\
\hline Coming from a Wealthy Family & 3.06 & 0.83 & 3.23 & 1.00 & -0.95 \\
\hline Having Well Educated Parents & 3.24 & 0.86 & 3.63 & 0.84 & $-2.25 *$ \\
\hline Having a Good Education Yourself & 4.27 & 0.78 & 4.55 & 0.50 & $-2.27 *$ \\
\hline Ambition & 4.47 & 0.74 & 4.55 & 0.60 & -0.58 \\
\hline Natural Ability & 3.47 & 0.83 & 3.55 & 0.90 & -0.46 \\
\hline Hard Work & 4.50 & 0.85 & 4.48 & 0.82 & 0.15 \\
\hline Knowing the Right People & 3.51 & 0.85 & 3.65 & 0.95 & -0.77 \\
\hline Political Connections & 2.60 & 0.92 & 2.70 & 0.99 & -0.53 \\
\hline Race & 2.16 & 1.02 & 2.48 & 1.20 & -1.48 \\
\hline Religion & 1.86 & 0.84 & 2.15 & 1.00 & -1.64 \\
\hline Part of the Country & 2.27 & 0.92 & 2.20 & 0.85 & 0.40 \\
\hline Being Born a Man or a Woman & 2.50 & 1.11 & 2.45 & 1.04 & 0.23 \\
\hline Political Beliefs & 2.10 & 0.90 & 2.20 & 0.97 & -0.55 \\
\hline
\end{tabular}

Note: Scales range from $1=$ Not At All Important to $5=$ Essential

As seen in Table 2.2, there were no statistically significant differences in attitudes toward factors affecting upward mobility between males and females when examining the pre-test data. In other words, both males and females have similar views on factors influencing mobility before participating in the simulation. This is inconsistent with research by Essed (1992) and Fegin and Sikes (1994) who found that students from subordinate groups (in this case females) internalize their lower position in the social hierarchy and are less likely than dominant groups (in this case males) to identify outside factors affecting mobility. However, when examining post test data (as 


\begin{tabular}{|c|c|c|c|c|c|}
\hline \multicolumn{6}{|c|}{ Table 2.4: T-Tests for Getting Ahead in Life (Females Only) } \\
\hline \multirow{2}{*}{$\begin{array}{l}\text { How important do you think each } \\
\text { of the following is for getting } \\
\text { ahead in life? }\end{array}$} & \multicolumn{2}{|c|}{$\begin{array}{c}\text { Pre-Test } \\
\mathrm{N}=41\end{array}$} & \multicolumn{2}{|c|}{$\begin{array}{c}\text { Post Test } \\
\mathbf{N}=\mathbf{7 0}\end{array}$} & \multirow[t]{2}{*}{ t-test } \\
\hline & Mean & SD & Mean & SD & \\
\hline Coming from a Wealthy Family & 2.73 & 0.90 & 3.06 & 0.83 & -1.93 \\
\hline Having Well Educated Parents & 3.27 & 0.74 & 3.24 & 0.86 & 0.16 \\
\hline Having a Good Education Yourself & 4.39 & 0.70 & 4.27 & 0.78 & 0.80 \\
\hline Ambition & 4.51 & 0.64 & 4.47 & 0.74 & 0.30 \\
\hline Natural Ability & 3.32 & 0.72 & 3.47 & 0.83 & -1.00 \\
\hline Hard Work & 4.68 & 0.57 & 4.50 & 0.85 & 1.36 \\
\hline Knowing the Right People & 3.39 & 0.83 & 3.51 & 0.85 & -0.75 \\
\hline Political Connections & 2.54 & 0.87 & 2.60 & 0.92 & -0.36 \\
\hline Race & 2.10 & 1.02 & 2.16 & 1.02 & -0.30 \\
\hline Religion & 1.66 & 0.73 & 1.86 & 0.84 & -1.26 \\
\hline Part of the Country & 2.00 & 0.74 & 2.27 & 0.92 & -1.70 \\
\hline Being Born a Man or a Woman & 2.15 & 0.88 & 2.50 & 1.11 & -1.85 \\
\hline Political Beliefs & 1.98 & 0.72 & 2.10 & 0.90 & -0.80 \\
\hline
\end{tabular}

Note: Scales range from $1=$ Not At All Important to $5=$ Essential

seen in Table 2.3), females were less likely to view 'having well educated parents' $(t=-2.25$; $\mathrm{p}<.05)$ and 'having a good education yourself' $(t=-2.27 ; \mathrm{p}<.05)$ as essential to getting ahead in life than males. This means that females, compared to males, start to view education as less essential to getting ahead in life after participation in the simulation. Females are often taught that the best way to improve their chances in life is through education (United Nations Population Fund n.d.). Perhaps by facing the structural barriers to mobility in the simulation they become more aware of the structural barriers in real life and start to believe that education is not 
as important or powerful for getting ahead in life. T-test results revealed no other statistically significant differences between male and female attitudes toward factors affecting upward mobility when examining post test data.

\begin{tabular}{lcc|cc|c}
\hline \multicolumn{7}{c}{ Table 2.5: T-Tests for Getting Ahead in Life (Males Only) } \\
\hline $\begin{array}{l}\text { How important do you think each } \\
\text { of the following is for getting }\end{array}$ & $\begin{array}{c}\text { Pre-Test } \\
\text { N=18 }\end{array}$ & \multicolumn{2}{c}{$\begin{array}{c}\text { Post Test } \\
\text { N=40 }\end{array}$} & t-test \\
& Mean & SD & Mean & SD & \\
\hline Coming from a Wealthy Family & 2.78 & 0.88 & 3.23 & 1.00 & -1.63 \\
Having Well Educated Parents & 3.56 & 0.51 & 3.63 & 0.84 & -0.33 \\
Having a Good Education Yourself & 4.33 & 0.49 & 4.55 & 0.50 & -1.53 \\
Ambition & 4.67 & 0.49 & 4.55 & 0.60 & 0.72 \\
Natural Ability & 3.28 & 0.67 & 3.55 & 0.90 & -1.14 \\
Hard Work & 4.56 & 0.62 & 4.48 & 0.82 & 0.37 \\
Knowing the Right People & 3.50 & 0.92 & 3.65 & 0.95 & -0.56 \\
Political Connections & 2.78 & 0.81 & 2.70 & 0.99 & 0.29 \\
Race & 2.50 & 0.71 & 2.48 & 1.20 & 0.08 \\
Religion & 2.00 & 1.24 & 2.15 & 1.00 & -0.49 \\
Part of the Country & 2.22 & 0.88 & 2.20 & 0.85 & 0.09 \\
Being Born a Man or a Woman & 2.39 & 0.92 & 2.45 & 1.04 & -0.22 \\
Political Beliefs & 2.33 & 0.77 & 2.20 & 0.97 & 0.52 \\
\hline
\end{tabular}

Note: Scales range from $1=$ Not At All Important to 5= Essential

Tables 2.4 and 2.5 show the t-test results for females and males respectively of factors affecting upward mobility by test. As can be seen in the tables, when examining differences by gender, no statistically significant appear between the pre-test and the post test. In other words, 
males and females do not experience any statistically or substantively significant shifts in attitudes following participation in the Star Power simulation. This refutes the first hypothesis and is inconsistent with previous research by Essed (1992), Fegin and Sikes (1994) and IrbyShansanmi, Oberlin, and Saunders (2012). However, this may also be due in part to the small sample size of the sub-groups.

\begin{tabular}{|c|c|c|c|c|c|}
\hline Table 2.6: T-Tests & Gettin & head & Life Pr & Test Da & \\
\hline $\begin{array}{l}\text { How important do you think each } \\
\text { of the following is for getting } \\
\text { ahead in life? }\end{array}$ & First & ars & $\begin{array}{r}\text { Soph } \\
\text { Juniors } \\
\mathrm{N}=\end{array}$ & $\begin{array}{l}\text { ore, } \\
\text { eniors } \\
6\end{array}$ & t-test \\
\hline & Mean & SD & Mean & SD & \\
\hline Coming from a Wealthy Family & 2.65 & 0.83 & 2.81 & 0.92 & -0.65 \\
\hline Having Well Educated Parents & 3.35 & 0.71 & 3.36 & 0.68 & -0.07 \\
\hline Having a Good Education Yourself & 4.43 & 0.59 & 4.33 & 0.68 & 0.59 \\
\hline Ambition & 4.57 & 0.66 & 4.56 & 0.56 & 0.60 \\
\hline Natural Ability & 3.26 & 0.81 & 3.33 & 0.63 & -0.38 \\
\hline Hard Work & 4.70 & 0.56 & 4.61 & 0.60 & 0.54 \\
\hline Knowing the Right People & 3.13 & 0.92 & 3.61 & 0.77 & $-2.17^{*}$ \\
\hline Political Connections & 2.48 & 0.73 & 2.69 & 0.92 & -0.95 \\
\hline Race & 2.04 & 1.02 & 2.33 & 0.89 & -1.15 \\
\hline Religion & 1.78 & 1.00 & 1.75 & 0.87 & 0.13 \\
\hline Part of the Country & 2.00 & 0.80 & 2.11 & 0.78 & -0.53 \\
\hline Being Born a Man or a Woman & 2.04 & 1.11 & 2.33 & 0.72 & -1.22 \\
\hline Political Beliefs & 1.83 & 0.83 & 2.25 & 0.65 & $-2.19^{*}$ \\
\hline
\end{tabular}

Note: Scales range from $1=$ Not At All Important to $5=$ Essential

* Significant at the .05 level 
Tables 2.6 through 2.9 show t-test results for attitudes towards factors affecting upward mobility and class standing. When examining pre-test data, statistically significant differences exist between first years and other classes when it comes to attitudes toward 'knowing the right people' and 'political beliefs' for getting ahead in life (see Table 2.6). Sophomores, Juniors, and Seniors, overall, reported higher levels of importance for 'knowing the right people' $(t=-2.17$; $\mathrm{p}<.05)$ and 'political beliefs' $(t=-2.19 ; \mathrm{p}<.05)$ than First Years on the pre-test. In other words, upperclassmen were more likely to report knowing the right people and political beliefs as

\begin{tabular}{|c|c|c|c|c|c|}
\hline \multirow[t]{2}{*}{$\begin{array}{l}\text { How important do you think each } \\
\text { of the following is for getting } \\
\text { ahead in life? }\end{array}$} & \multicolumn{2}{|c|}{$\begin{array}{c}\text { First Years } \\
\mathrm{N}=41\end{array}$} & \multicolumn{2}{|c|}{$\begin{array}{c}\text { Sophomore, } \\
\text { Juniors, Seniors } \\
\text { N=69 }\end{array}$} & \multirow[t]{2}{*}{ t-test } \\
\hline & Mean & SD & Mean & SD & \\
\hline Coming from a Wealthy Family & 3.24 & 1.04 & 3.04 & 0.79 & 1.06 \\
\hline Having Well Educated Parents & 3.46 & 0.90 & 3.33 & 0.85 & 0.76 \\
\hline Having a Good Education Yourself & 4.34 & 0.73 & 4.39 & 0.69 & -0.36 \\
\hline Ambition & 4.54 & 0.67 & 4.48 & 0.70 & 0.43 \\
\hline Natural Ability & 3.51 & 0.98 & 3.49 & 0.78 & 0.11 \\
\hline Hard Work & 4.37 & 1.09 & 4.57 & 0.63 & -1.07 \\
\hline Knowing the Right People & 3.59 & 1.00 & 3.55 & 0.81 & 0.20 \\
\hline Political Connections & 2.80 & 1.03 & 2.53 & 0.88 & 1.45 \\
\hline Race & 2.27 & 1.34 & 2.28 & 0.92 & -0.03 \\
\hline Religion & 1.88 & 1.03 & 2.02 & 0.83 & -0.76 \\
\hline Part of the Country & 2.34 & 0.96 & 2.19 & 0.84 & 0.87 \\
\hline Being Born a Man or a Woman & 2.54 & 1.10 & 2.45 & 1.08 & 0.41 \\
\hline Political Beliefs & 2.29 & 1.03 & 2.04 & 0.85 & 1.31 \\
\hline
\end{tabular}

Note: Scales range from $1=$ Not At All Important to $5=$ Essential 
important for getting ahead in life than first years before participating in the simulation.

Upperclassmen have had more experience than first years in with situations where 'knowing the right people' can be essential, such as finding jobs and internships. So it would make sense that they view knowing the right people are more essential to getting ahead in life than first years. In addition, upperclassmen are all of age that they could have participated in multiple political elections. More specifically, some of the upperclassmen in the sample could have participated in

\begin{tabular}{|c|c|c|c|c|c|}
\hline \multicolumn{6}{|c|}{ Table 2.8: T-Tests for Getting Ahead in Life (First Years Only) } \\
\hline \multirow{2}{*}{$\begin{array}{l}\text { How important do you think each } \\
\text { of the following is for getting } \\
\text { ahead in life? }\end{array}$} & \multicolumn{2}{|c|}{$\begin{array}{c}\text { Pre-Test } \\
\mathrm{N}=36\end{array}$} & \multicolumn{2}{|c|}{$\begin{array}{c}\text { Post Test } \\
\mathrm{N}=69\end{array}$} & \multirow[t]{2}{*}{ t-test } \\
\hline & Mean & SD & Mean & SD & \\
\hline Coming from a Wealthy Family & 2.81 & 0.92 & 3.04 & 0.79 & -1.32 \\
\hline Having Well Educated Parents & 3.36 & 0.68 & 3.33 & 0.85 & 0.17 \\
\hline Having a Good Education Yourself & 4.33 & 0.68 & 4.39 & 0.69 & -0.41 \\
\hline Ambition & 4.56 & 0.56 & 4.48 & 0.70 & 0.58 \\
\hline Natural Ability & 3.33 & 0.63 & 3.49 & 0.78 & -1.06 \\
\hline Hard Work & 4.61 & 0.60 & 4.57 & 0.63 & 0.36 \\
\hline Knowing the Right People & 3.61 & 0.77 & 3.55 & 0.81 & 0.37 \\
\hline Political Connections & 2.69 & 0.92 & 2.53 & 0.88 & 0.86 \\
\hline Race & 2.33 & 0.89 & 2.78 & 0.92 & 0.31 \\
\hline Religion & 1.75 & 0.87 & 2.01 & 0.83 & -1.52 \\
\hline Part of the Country & 2.11 & 0.78 & 2.19 & 0.84 & -0.46 \\
\hline Being Born a Man or a Woman & 2.33 & 0.72 & 2.45 & 1.08 & -0.66 \\
\hline Political Beliefs & 2.25 & 0.65 & 2.04 & 0.85 & 1.28 \\
\hline
\end{tabular}

Note: Scales range from $1=$ Not At All Important to 5= Essential 


\begin{tabular}{lcc|cc|c}
\hline \multicolumn{3}{c}{ Table 2.9: T-Tests for Getting Ahead in Life (Sophomore, Juniors, and Seniors) } \\
\hline $\begin{array}{l}\text { How important do you think each } \\
\text { of the following is for getting }\end{array}$ & $\begin{array}{c}\text { Pre-Test } \\
\text { N=23 }\end{array}$ & \multicolumn{2}{c}{$\begin{array}{c}\text { Post Test } \\
\text { N=41 }\end{array}$} & t-test \\
ahead in life? & Mean & SD & Mean & SD & \\
\hline Coming from a Wealthy Family & 2.65 & 0.83 & 3.24 & 1.04 & $-2.33^{*}$ \\
Having Well Educated Parents & 3.35 & 0.71 & 3.46 & 0.90 & -0.53 \\
Having a Good Education Yourself & 4.43 & 0.59 & 4.34 & 0.73 & 0.53 \\
Ambition & 4.57 & 0.66 & 4.54 & 0.67 & 0.16 \\
Natural Ability & 3.26 & 0.81 & 3.51 & 0.98 & -1.05 \\
Hard Work & 4.70 & 0.56 & 4.37 & 1.09 & 1.60 \\
Knowing the Right People & 3.13 & 0.92 & 3.59 & 1.00 & -1.80 \\
Political Connections & 2.48 & 0.73 & 2.80 & 1.03 & -1.34 \\
Race & 2.04 & 1.02 & 2.27 & 1.34 & -0.75 \\
Religion & 1.78 & 1.00 & 1.87 & 1.03 & -0.36 \\
Part of the Country & 2.00 & 0.80 & 2.34 & 0.96 & -1.44 \\
\hline
\end{tabular}

Note: Scales range from $1=$ Not At All Important to $5=$ Essential

* Significant at the .05 level

both the 2008 and 2012 Presidential elections. Thus, it would make sense that Sophomores, Juniors, and Seniors view political beliefs as more essential to getting ahead in life than first years. However, following participation in the Star Power simulation, these relationships disappear and no statistically significant differences exist between first years and sophomores/juniors/seniors attitudes towards factors for getting ahead in life (see Table 2.7). 
When examining first year students on their own, no statistically or substantively significant differences exist in attitudes towards factors affecting upward mobility after participation in the Star Power simulation (see Table 2.8). However, Table 2.9 shows, sophomore, juniors, and seniors, viewed 'coming from a wealth family' as more essential to getting ahead in life after participation in the Star Power simulation $(t=-2.33 ; \mathrm{p}<.05)$. This supports the second hypothesis and Astin's theory of involvement which stated that sophomores, juniors, and seniors would experience the greatest change in attitudes following participation in the Star Power simulation.

In summary, students in the net generation view Star Power as a worthwhile experience across the board. In addition, overall, participation in the Star Power simulation does result in a shift of views toward recognition of structural factors as more essential to upward mobility. Furthermore, little to no differences occurs in attitudes between groups. In other words, it appears that Star Power is experienced similarly by different social groups (gender and class standing) within the classroom.

\section{Qualitative Analysis}

All students enrolled in SO 101: Discovering Society were required to write a reflection paper following their participation in the Star Power simulation and after being exposed to assigned stratification/inequality readings, discussion, and lectures. For Part B of the paper, students are asked to define and connect at least three class concepts to their simulation experience. From a review of 126 reflection papers from four sections of the course, 66 different terms were identified in connection with the Star Power (see Appendix D for a complete list of terms). 
The most common term connected with the Star Power simulation was "inequality" or "social inequality", with 52.4 percent of students including it in their reflection paper. A typical example of how inequality was connected to the simulation and included in the reflection papers is as follows:

"The final class concept that I saw during this simulation was that of social inequality. Social inequality is a condition in which members of a society have different amounts of wealth and prestige. I knew there was going to be some amount of inequality once the concepts of chips and points was brought into play but it took until the game really got going for me to see the real extent of the inequality between groups. There were some huge differences in the abilities of the groups that brought out the extent of these inequalities to its fullest. As soon as the squares started getting bags with better chips and the ability to make their own rules they were put in a class of their own, un-paralleled by the other two groups. There was only a little difference between the triangles and the circles but it still caused much separation. First of all, the triangles were still about to collect new chips after each round while the circles did not even have that luxury at the end. And second, once labelled a circle no one would want to trade with you besides other circles. Once people from the higher levels saw that circle pin all they assumed was that your chips cannot be good because they do not have many points so why should I trade with them. Towards the end the social inequality between groups was so great that there was hardly any movement between groups and the ruck just kept getting richer and the poor just kept getting poorer."

The next most common term was "stratification" or "social stratification", with 42.9

percent of students including it in their reflection paper. A typical example of how stratification

was connected to the simulation and included in the reflection papers is as follows:

"Another class concept that was touched upon in the simulation was stratification. Stratification is a structured ranking of groups that perpetuates unequal rewards and power in society. This was obviously displayed during the Star Power simulation. The triangle, circle, and square pins were the groups that were structurally ranked. The squares being the highest class, triangles the middle class, and circles the lowest class. Due to these rankings the squares got unequal economic rewards, such as the ability to make game rules and picking from a more lucrative coin stack. These things led to the stratification during Star Power."

The third most common term identified by students was "social structure", which was included in 39.7 percent of papers. A typical example of how social structure was connected to the simulation and included in the reflection papers is as follows: 
"Social structure, which refers to the organization of a society into predictable relationships, was a very prominent theme throughout this simulation (class notes). The players too the three possible shapes and assigned meaning to each in order to create a society that was divided into three different parts. There was a structural hierarchy of social classes formed which lasted throughout the simulation. In the beginning, the overall goal of the players seemed to be to either move into or remain in the square group. However, as the simulation continued, the ties between members of the same group began to strengthen as the differences in point values, strategic beliefs, purposed of the game and even enjoyment of the game began to differ between groups. For example, the "squares" continued to want to shut everyone else out of our group, while the "triangles" began to view the game as a revolution against the "squares", and the "circles" just became tired of the game. The relationships between group members were predictably friendlier than trading relationships between members of different groups. This became especially true as the conflict between groups began to increase when the "squares" began to make unfair rules."

This shows that students are successfully linking their simulation experience with concepts and class material from the unit for which it was intended (stratification and inequality). In fact, 100 percent of students included at least one concept from the Stratification and Inequality unit in their reflection paper.

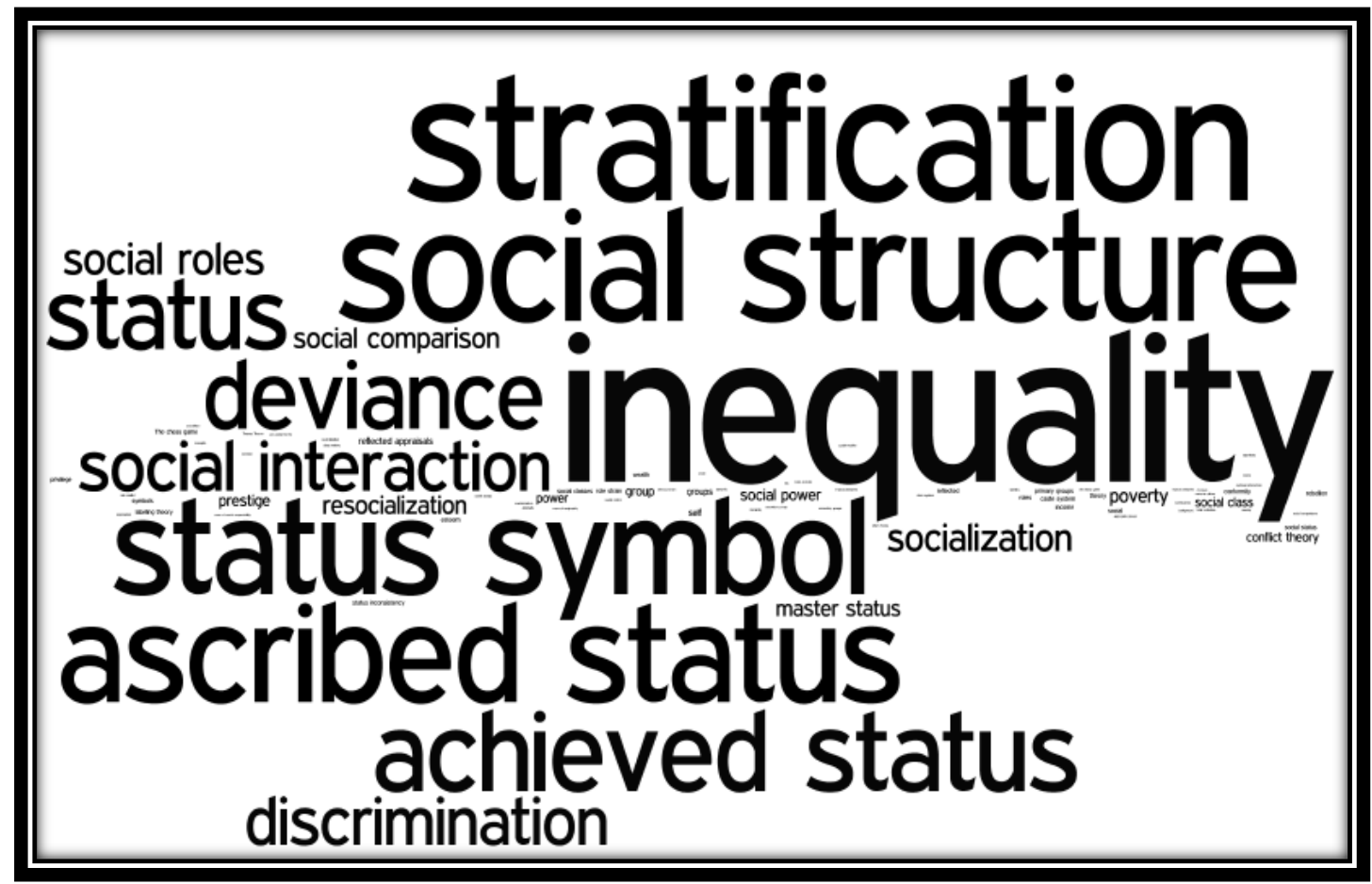

Figure 1: Word Cloud of all terms identified in reflection papers. Generated by Wordle. 
Figure 1 depicts a word cloud of all terms identified in Part B of reflection papers by students. In addition to inequality, stratification, and social structure, some of the most commonly identified terms were ascribed status, status symbol, and achieved status. Interestingly, "ascribed status" was mentioned in 34.9 percent of papers while "achieved status" was only mentioned in 28.6 percent of papers. This may be because discussion following the simulation focuses on how statuses are ascribed during the game and how it impacts individuals throughout the remained of the simulation.

In Part B of the reflection assignment, students are also asked to describe their perceptions of Star Power as a learning tool and explain if they would recommend the simulation be used in future classes. First, all but two students recommended that Star Power be used again in future classes. Even the students who did not recommend that Star Power be used again mentioned it helped them learn and that they saw some value in the simulation. One student stated,

"The simulation did help me learn about how the social classes work. Also about our concepts from class such as social structure, social interaction, deviance, social power, status symbol, inequality. All of those were demonstrated in the Star Power simulation. I do not recommend this simulation for next year. I felt like it was too confusing and I did not have that much fun with it. This could be just because I did not fully understand the rules. Perhaps explaining the rules better and having more practice rounds would help. I thought the simulation was not good and I feel there could be a better way to show all the concepts in a more understanding way."

In addition, the other student said,

"Star Power was a good learning tool. It taught and demonstrated many class concepts, including social interaction, social structure, deviance, social power, inequality, status symbols, status, roles, and inequality...However, StarPower didn't really demonstrate how complicated our society and these concepts really are. It didn't take into account the situations where the poor, for example, are able to work hard, find jobs and scholarships, and improve their lives and the lives of their families. It didn't show how upper class people at least sometime try to help others (like Bill Gates, for example) and work to improve society and/or reject status symbols. Overall, I think it is good and bad. It 
seemed boring to me after a while, especially because it took so long to play. Additionally, I felt that I understood the concepts clearly before the simulation. Although it was a bit boring I thought it did demonstrate the norms of society. I would probably not recommend that you use it for next year's class."

Aside from these two students, all other students recommended the simulation be used again, with the majority of students being very adamant that Star Power be used again in future classes. For instance,

"Star Power should be used next semester and every semester to come because this game will enlighten students and make them aware of the sickening conformity in which we participate in. This game will shed light on a system which we know is enacted but do little to change, and it may motivate people to do something different every day. Even if a student walks away from Discovering Society having participated in these simulations they will forever be changed, because whether they agree with systems enacted in our society or not, or whether students care or not, they will always be aware of what is going on in their environment. Once one's eyes have been opened to the society in which we live more thoroughly, that cannot be undone, and students will be able to deeply think about the decisions they make in their daily lives instead of unconsciously going through every day norms with no thought or meaning."

Another student said, "I highly recommend this simulation in future classes since it opens our eyes to the troubling issues that even our society, and helps us understand the forces behind much of the conflict between the classes, and how and why they are created. The lessons of this simulation are invaluable for any student of any field of study." Importantly, differences between what group the student was in during the simulation (Square, Triangle, Circle) and overall perceptions of the simulation as a learning tool did not seem to occur in the reflection papers. These findings are consistent with research by Allen (2008), Carranza (1974), Dukes (1986), Dukes and Waller (1976), Dundes and Harlow ( 2005), Humphrey (1970), Jackson (1979), and Nikkel (1976) who found participants in Star Power perceived the simulation as beneficial, a valuable learning tool, and recommend it for future use.

After a review of the 126 reflection papers, the following six major themes related to student perceptions of the value of Star Power as a learning tool were identified. The first, and 
most common theme, was that students believed Star Power was a valuable learning tool

because it allowed them to "experience the concepts." As one student put it

"It made it easier to relate to each specific class. Being able to relate the squares to the upper class in society made people realize how and why some people become corrupt. Being in the triangles made people feel like they were in the middle class. They felt satisfied with where they were but they still felt like they had something to work towards. The circles could relate to how the lower class feels. They realized that once you're down its hard to come back from low income or debt or in our case, chips. Overall, I believe this simulation is a great learning tool and should continue to be used with future classes."

This same sentiment was reflected in more than half of the reflection papers. Another student commented,

"I definitely think actually experiencing a class concept is a much better way to learn and understand that concept than simply reading about it in a textbook. As Star Power provided a "real life" experience illustrating several class concepts such as social structure, status (ascribed and achieved) and status symbols, I feel much more comfortable with these terms. I was able, for example, to better appreciate how one's status is ascribed at birth (represented by drawing the initial five chips) and how it may be difficult to break out of one's initially ascribed social status."

These responses were representative of other students who reported enjoying and seeing value in the simulation because of being able to experience the concepts. In addition, the largely middle class student population stated that they were able to personally experience what it was like to be a member of the lower or upper social classes. One student said,

"I think that Star Power is a very interesting learning tool because probably most of the students come from a middle-accommodated class which would be represented by the triangles, but most of us do not know how it feels to be at the top or the bottom of society...I would recommend this simulation for this and any other social classes, because it gives you a different perspective of how social reality is."

This is consistent with research by Davis (1992) who mentions that Star Power provides a way for students to experience social inequality and stratification in way that they may never have before. It is also consistent with previous research which states that by actually "living" the experiences during the simulation, students are more motivated and interested in the topic as 
compared to simply reading about or discussing the concepts (Dorn 1989; Bruin 1985; Davis 1992).

Another student had a realization about being able to experience what it is like to be a member of the upper class. He stated,

"After doing the star power simulation I would recommend that you use it again next semester because learning about social power and social groups does not always make complete sense in class because I always said I would never be like that if I was rich I would give back a lot more than most rich people but I was a square and I had a part in making sure the lower class could not move up. This was a good experience to see that I thought differently when I actually had power."

This is also consistent with previous research which states that it is incredibly rare that students do not take advantage of their opportunity to use power to exploit other groups (Davis 1992).

Overall, the students were able to relate to and experience a social class situation different from their own which they found extremely valuable.

The second most common theme mentioned by students were that they enjoyed the simulation because it was fun and different from 'normal' class. Many student expressed that they thought the simulation should be used again because they had a lot of fun playing. For example, "I would definitely recommend using the Star Power simulation again next year because it was a fun way to learn about social structure." In addition, they said that should be used again because it was different from a normal, lecture-based class. As one student stated, "I enjoyed the simulations in this course because it is different from how most of my classes are run. Learning through a power point or book is helpful, but being able to simulate a situation and relate it to what we are learning in the classroom is very beneficial." Many stated that the simulation enabled them to learn and apply the material instead of just memorizing. As one student remarked, "It is an excellent way to educate students on a variety of different topics in society without having to read off of a PowerPoint." Similarly, another student from the net 
generation commented, "Doing the simulation helped me because I'm a visual and hands-on learner and Star Power was a great way to learn about social topics that were new to me."

These findings are consistent with what Tapscott (2009) outlined as the norms of the net generation. Students in the net generation want their learning experience to be customizable and fun, and they want to be active participants (Tapscott 1997; Hay 2000; Carlson 2005; Tapscott 2009). The Star Power simulation provides an experience that is different from passive lecture and note taking which allows students to be active and more hands-on.

The third most common theme that students mentioned about their perceptions of the value of Star Power was the utility of the experience for increasing their understanding of the concepts of social power, inequality, social structure, social class, stratification, social mobility, achieved/ascribed statuses, deviance, and ethnocentrism. As summarized by a square from the simulation, "I think the most important aspect we gained was an awareness of inequality." Similarly, a circle from the simulation wrote, "Without this simulation, I believe that I would still not fully understand the different statues and would not have gotten the first-hand experience of the relationship and interaction of each class." Also, another student stated, "This simulation allowed me to experience a deeper and more thorough understanding of sociological concepts than I otherwise would not have thought to look at or even noticed." Furthermore, students reflected on the long-term impact of the simulation. As one student commented, "Personally, I know that I will remember the terms that I learned from this unit because of this simulation." Another stated, "I would recommend that you keep using Star Power for as long as we live in the society we do."

The fourth theme to emerge was a noted change in self-awareness, with Star Power being referred to as eye-opening, thought-provoking, or a wake-up call. As one student mentioned, "I 
learned there is a lot of inequality in our society. The fact that some have so much power and wealth and others are forced to scratch and claw their way to survive was mind boggling." In addition, some students began to think more critically about the 'American Dream' and their role in society. For instance,

"It [Star Power] made me realize the struggles of the lower class to move up in society. I find myself wondering, 'How easy is it to have the American dream? To go from rages to riches. Is it possible?" In the end, I realize with hard work and education it can be done, but not without a lot of sacrifice. As a result of this simulation, it makes me more appreciative of what I have. It also makes me want to do more for the poor because I feel that I understand where they are coming from."

Students also mentioned how surprised they were at their own behavior and the behavior of their classmates. One woman commented,

"It is sick how a bunch of young college students can turn against each other in a matter of an hour and a half. It surprised me how emotionally invested and driven the individuals in this class got over a game. It was like the Zimbardo Prison Experiment, everyone played their given role. It became real for the players. For example the squares really believed they were the best and the circles were looked down on. After the debriefing this is when things started to come back to normal. I think it is amazing how that can happen, how humans take a fictional role and make it so real. Despite everything this is a great simulation."

Another student stated,

"It was a very eye-opening experience for me. I knew already that our system wasn't the best, but I had no idea that even in a simulation that wasn't real, people would act in the crazy ways that they did. One could argue that it was "just a game", but it was designed to mirror real life situations. I shudder to think what those who had the fictions power would do if they had even an inkling of "real" power. I was rather disturbed by the whole ordeal, but in a good way, I think."

For members of racial or ethnic minority groups, the simulation wasn't just a game. One such

student commented,

"To me, this simulation was more than just a game. It represented the racial discrimination that I face each and every day of my life. For the majority of the simulation, I was a part of the circle group. People were moaning and groaning for when the game would be over. It is true what they say that all comes to a halt with time. Such being the case, these individuals, at the very strike of $4 \mathrm{pm}$ will have regained social 
justice. But what about me? Unfortunately, the same does not apply. I will serve this sentence for life, unlike a majority of the population. I will be dragging the shackles on my feet for life, but I have always done so with a smile. That being said, I honestly think that Dr. Koz should continue using this simulation for years to come."

Similarly, the fifth most prevalent theme was individuals who had a negative view of the simulation or personally had a negative experience, but would still recommend that Star Power be repeated in future classes. This is one area where the group an individual participated in during the simulation (circle, triangle, square) impacted their overall feelings toward the game.

One circle stated,

"The meaning of inequality really hit hard when I was personally affected by the worst of it during the simulation as a circle. I really felt terrible when the squares were laughing having a great time while the circles seemed down in the dumps and depressed due to how unfair they were being treated...Although being a circle for the entire time of the simulation may have been a downfall of the actual game, it definitely opened my perspective of the reality in which we live today."

Another circle wrote that,

"Being a circle, I received a glimpse of how tough it is to be lower class. Everyone treats you differently, and after a while, you just end up giving up hope... In Star Power, never once did the advisor say, "The squares are representing the upper class, the triangles the middle class, and the circles are the lower class." We just separated and thought of ourselves as part of those classes...It just saddened me to see that our society reacts pretty much the same way. Although I still have a negative view towards Star Power due to previously mentioned reasons, I think that Star Power should definitely be used again next semester."

This same sentiment was echoed by the majority of the circles, for example, "even though I was a circle the majority of the game and wanted it to end as soon as possible, I still think it is a good activity for students in sociology class to participate in" and "In terms of a "game", I did not find it as enjoyable as Barnga, but that was because trading rounds were frustrating when movement is not occurring. But I recommend reusing it since this accurately represents the struggles faced by the lower class." 
It should be noted that students who were participants in the square (upper class) group identified that they were significantly happier during the simulation than those in the circle or triangle groups. Likewise, those from the circle groups, were much more likely to comment that they did not enjoy the simulation, but recognized the benefit of that experience as well. In contrast to the negative feelings voiced by the circles above, one square wrote,

"As a learning tool, I definitely loved Star Power. It was all I could talk about for a couple of days after playing it...It is empowering because when you have the highest point value in the room, you feel untouchable because no one else is on your level. You feel like the ball is in your court and you can do whatever you want without anyone being able to stop you because you are "on top of the world."... I highly recommend that you continue to use the simulation. It teaches a valuable lesson about how society works, but it does so in a way that is highly interactive and fun. I personally enjoyed it because I was a square for the whole game, which I'm sure is why I liked it so much... This was probably my favorite of the two simulations and I'm glad that I could partake in it."

These feelings of elation and positivity toward the simulation were very common among individuals who experienced the whole simulation as a square.

Sixth, the final major theme that emerged in the reflection papers was students mentioning increasing social interaction of cohesion within and between members of the sections of the course as a beneficial outcome of the simulation. Several students stated that they enjoyed being able to meet and interact with people that wouldn't have if it weren't for the simulation. For example, "I also liked meeting people in the other Discovering Society section. Without the Star Power simulation I would have never met some of the other people in the other Discovering Society class." and "Also it [Star Power] can help students interact amongst each other people, seeing that I was the more social during this simulation than any other time in class, also people definitely got to know others a bit more during this activity." Similarly, another student mentioned,

"This shows that even if you have a class all semester long, it may be hard to get to know the other students in your section. This activity was a huge success and should continue 
to be held for future classes because it allows students to get to know their peers while learning an extremely important aspects of the real-world today."

Although surprising that it emerged as one of the major themes, these findings are consistent with previous research (Wilson 2004; Howe and Strauss 2003). Students in the net generation are team-oriented and highly value group work and collaboration. As a result, it makes sense that students would see getting to know more individuals in their class and other classes as well as increased social interaction as a benefit of the simulation.

Overall, although personal feelings about the simulation itself may vary, the overwhelming majority of students perceive Star Power as beneficial and a valuable learning tool which they recommend should continue to be used in future classes. Analysis of the reflection papers reveled remarkable comprehension, application of the material, concept identification, changes in self-awareness and increased social interaction.

\section{Discussion and Conclusion}

This research builds upon the existing literature in four important ways. First, this research examined the perceived value of Star Power as a teaching tool and the effectiveness of the simulation in teaching core sociological concepts such as social stratification and inequality to the net generation. To examine the effectiveness of Star Power for teaching core sociological concepts responses to closed-ended questions modified from the Social Inequality Module of the GSS were analyzed. This study was also the first since 1979 to use a pre-posttest comparison to examine the effectiveness of Star Power and found several substantive changes in factors influencing upward mobility following the simulation in addition to five statistically significant relationships. The statistically significant relationships reflected changing views of the importance of coming from a wealthy family, hard work, religion, part of the country and being born a man or a woman. 
After participation in the simulation, students viewed several structural level factors such as coming from a wealthy family, religion, part of the country someone is from, and being born a man or a woman as more essential to getting ahead in life than they did before the simulation. Participants also viewed hard work as less essential to getting ahead in life after participation in the simulation. These findings suggest that the simulation was effective in changing views and fostered a greater understanding of the class material and concepts.

These findings also revealed some interesting trends. One example is students viewed religion as more essential to getting ahead in life after participating in Star Power. This suggests that students view religion as an ascribed status and along the same lines as gender and coming from a wealthy family. This is something that may be unique to the net generation. While research suggests that the net generation looks to religion for guidance less than any other generation (Neuman 2014) they are also more tolerant of all religions, even as negative attitudes toward Muslims and Islam has continued to rise overall since the 9/11 attacks (Towns 2011). Even more interesting, 70 percent of net geners believe that religious groups are "alienating young Americans by being too judgmental on gay and lesbian issues" and nearly one-third of net geners who have left the religion they were raised in did so because of the negative teachings or treatment related to gays and lesbians (Kaleem 2014). So, this shift in attitudes suggests that students' viewed religion as even more structural after participation in Star Power.

While it is clear that students are experiencing a shift in attitudes toward certain structural barriers to mobility, it remains unclear exactly how and why students are answering these questions in this way. It is also not clear why students are experience shifts in attitudes toward certain characteristics, for example religion and part of the country, but not others, such as race. Future research should examine in more detail the net generations' perceptions of concepts such 
as race, religion, and part of the country, especially in terms of structural vs. individual forces. For example, when they are asked how essential do they think race is for getting ahead in life, are they answering 'not at all' because they think it should not be essential, they do not think it is essential, or for some other reason. Future research should also examine how and why students relate the Star Power simulation to specific real-life situations not explicitly talked about in the game (such as religion) but not others (such as race).

Second, using quantitative methodology, this study filled a gap in the literature by being the first study to examine subgroup differences in relation to Star Power. More specifically this study examined the effects of gender and class standing on changes in students' views toward factors affecting upward mobility after participation in the simulation. While several statistical relationships were found in the aggregate data, only one appeared when examining social groups separately. Neither of the two hypotheses were entirely supported. Comparison of pre and post test data revealed no significant differences between males and females attitudes towards factors affecting upward mobility on the pre-test, but females viewed education related items as less essential to mobility following participation in Star Power.

When examining class standing, only one statistically significant difference occurred, with sophomores, juniors, seniors viewing coming from a wealthy family as more essential to getting ahead in life following the simulation. Overall, these results are very encouraging and suggest that the simulation is equally effective at changing views across groups and is not more or less beneficial for any specific group. This study was the first to examine if various groups experience Star Power similarly by examining subgroup differences so future research should examine these potential differences across other types of groups (such as major, residence, SES, race, etc.) as well as with larger sample sizes. 
Third, this study updated the literature by examining the perceived value of the Star Power simulation by the net generation. This study was also the first study to use a mixed methods approach to examine Star Power, resulting in a more complex and rich set of data. Most of the previous research on Star Power was conducted in the 1970s (Humphreys 1970; Jackson 1979; Tamminga 1977) and the studies on Star Power using the net generation focused mainly on observations and course evaluations (Dundes and Harlow 2005) and the simulation in a modified format (Allen 2008). This study, consistent with previous research by Allen (2008), Dundes and Harlow (2005), Humphrey (1970), and Tamminga (1977), found that 100 percent of students find Star Power worthwhile and all but two (98\%) recommend it be used in future classes. In addition, an analysis of reflection papers revealed the following six themes in relation to perceived value of the simulation: 1 . Being able to "experience the concepts"; 2 . Different from a normal, lecture-based class; 3 . Increased understanding of the concepts; 4 . Change in selfawareness; 5. Negative personal experience, but still recommend; 6. Increased class cohesion.

Fourth, this study examined which introductory sociology concepts undergraduate students linked with their Star Power experience. While 66 distinct terms were identified by students, the most common concepts were inequality $(52.4 \%)$, stratification $(42.9 \%)$, and social structure $(39.7 \%)$. Analysis of the reflection papers also showed that all students were able to successfully link at least one course concept with their simulation experience. Compared to the survey data, the reflection papers also better captured students' understanding of the material. Possible rationale for a greater understanding shown in the reflection papers, as compared to the survey, can be framed in cognitive dissonance. According to Piaget (1929), cognitive dissonance is a means to facilitate the cognitive process of accommodation and assimilation, which are central to the development of knowledge (cited by Adcock 2014). In order for students to learn 
and to make meaning of what they are learning they must be placed in situations that challenge their thoughts/beliefs. When their thoughts/beliefs are challenged they feel uncomfortable and experience dissonance. Star Power induces this dissonance. The reflection papers are a necessary task to help students develop these new perspectives and as a way to engage students in making meaning of their experience. So quantitative results are not as robust as the qualitative findings because while Star Power creates cognitive dissonance, the concepts then have to be placed in a context with time for reflection. This suggests that Star Power is a useful tool in the instructor's arsenal however, it is not sufficient in teaching the core concepts of sociology on its own.

There were a few limitations of this study. To begin with, the data were only available from four sections of SOC 101 at one institution. Drawing from only one institution created a limited sample. However, future research could examine the transferability of this technique across different types of classes and institutions. In addition, students in the first two sections of the course were not asked to answer demographic questions on the pre-test. This limited possible analyses across different groups.

Given the central role that stratification and inequality plays in the discipline of sociology, it is vital that instructors find innovative and effective ways to teach these concepts in a way that students remember and understand. The findings of this research will be beneficial for Sociology 101 instructors, instructors of other courses where stratification and inequality are taught, as well as diversity offices and programs by providing an example of a classroom activity and assessment that can be utilized. It is clear that students perceive Star Power as a worthwhile experience and are able to apply class concepts to their experience. In addition, students enjoy participating in the simulation and have linked their experience with increased knowledge and 
understanding of the concepts beyond what they gain from reading or lecture alone. It is expected that these learning styles and preferences of the net generation will continue into the next generation as well. While elements of the passive nature of the standard format of classes such as lecture are still vital to learning, simulations such as Star Power can help bring the concepts to life for the experientially based net generation. 


\section{References}

Abelev, Melissa, Bess Vincent, and Timothy Haney. 2008. “The Bottom Line: An Exercise to Help Students Understand How Social Inequality is Actively Constructed." Teaching Sociology 36(2): 150-60.

Adcock, Amy. 2014. "Cognitive Dissonance in the Learning Process.” Retrieved from http://www.springerreference.com/docs/html/chapterdbid/319474.html

Allen, Scott J. 2008. "Simulations as a Source of Learning: Using Star Power to Teach Ethical Leadership and Management.” Journal of Leadership Education 7(1): 140-149.

Astin, Alexander W. 1999. "Student Involvement: A developmental theory for higher education." Journal of College Student Development. 40(5): 518-529.

Barnes, Kassandra, Raymond C. Marateo, and S. Pixy Ferris. 2007. "Teaching and Learning with the Net Generation." Journal of Online Education.

Berkowitz, Dana, Namita N. Manohar, and Justine E. Tinkler. 2010. "Walk Like a Man, Talk Like a Woman: Teaching the Social Construction of Gender.” Teaching Sociology 38(2): 132- 143.

Birnbaum, Robert. 1982. "Games and Simulations in Higher Education.” Simulation and Games $13: 3-11$.

Boocock, Sarane S. and James S. Coleman. 1966. "Games with Simulated Environments in Learning." Sociology of Education. 39: 215-236.

Brislen, William and Clayton D. Peoples. 2005. "Using a Hypothetical Distribution of Grades to Introduce Social Stratification.” Teaching Sociology 33: 74-80.

Bruin, Klaas. 1985. "Prejudices, Discrimination, and Simulation/Gaming.” Simulation and Games. 16: 161-173.

Brezina, Timothy. 1996. “Teaching Inequality: A Simple Counterfactual Exercise.” Teaching 
Sociology 24(2): 218-24.

Carlson, Scott. 2005, October 7. "The Net Generation Goes to College.” The Chronicle of Higher Education: Information Technology. Retrieved from http://chronicle.com/article/The-Net-Generation-Goes-to/12307.

Carlson, Elwood. 2009. "20 th Century US-Generations." Population Bulletin 64(1). Retrieved from http://www.prb.org/pdf09/64.1generations.pdf.

Carranza, Elihu. 1974. “An Assessment of the Star Power Game." Simulation and Games 5: 219221.

Chickering, Arthur W. and Zelda F. Gamson. 1987. "Seven Principles For Good Practice In Undergraduate Education. AAHE Bulletin, 3-7.

Coghlan, Catherine L., and Denise W. Huggins. 2004. "'That's Not Fair": A Simulation Exercise in Social Stratification and Social Inequality." Teaching Sociology 32: 177-187.

CollegeBoard. 2013. "Elizabethtown College.” Retrieved September 9, 2013 (https://bigfuture.collegeboard.org/college-university-search/elizabethtowncollege ? searchType $=$ college $\& q=$ ElizabethtownCollege $)$.

Collins-Mayo, Sylvia and Bob Collins. 2006. Making Sense of Generation Y: The World View of 15-to 25-year-olds. London: Church House Publishing.

Corbeil, Pierre. 2011. "Introducing History into STARPOWER.” Simulation \& Gaming 42(4): 476-480.

Davis, Nancy J. 1992. “Teaching about Inequality: Student Resistance, Paralysis, and Rage." Teaching Sociology 20(3): 232-238.

Dezure, Deborah. n.d. "Higher Education Curriculum - National Reports On The Undergraduate 
Curriculum, Traditional And Contemporary Perspectives - Innovations in the Undergraduate Curriculum.” Retrieved from http://education.stateuniversity.com/pages/1896/Curriculum-Higher-Education.html

Dorn, Dean S. 1989. "Simulation Games: One More Tool on the Pedagogical Shelf." Teaching Sociology 17(1): 1-18.

Dukes, Richard L. 1974. "A Test of Multivariate Model in Two Types of Simulated Social Systems." Simulation \& Gaming 5(1): 23-46.

Dukes, Richard L. 1986. “Game Review.” Simulation and Games. 17: 121-126.

Dukes, Richard L. and Suzan J. Waller. 1976. “Toward a General Evaluation Model for Simulation Games: Gem." Simulation and Games. 7: 75-96.

Dundes, Lauren and Roxanna Harlow. 2005. "Illustrating the Nature of Social Inequality with the Simulation Star Power." Teaching Sociology 33(1): 32-43.

Eells, Laura Workman. 1987. "So Inequality is Fair? Demonstrating Structured Inequality in the Classroom." Teaching Sociology. 15: 73-75.

Essed, Philomena. 1992. Understanding Everyday Racism: An Interdisciplinary Theory. London: Sage.

Feagin, Joe R. and Melvin P. Sikes. 1994. Living with Racism: The Black Middle Class Experience. Boston: Beacon Press.

Garoutte, Lisa and Donna Bobbitt-Zeher. 2011. “Changing Students' Perceptions of Inequality?: Combining Traditional Methods and a Budget Exercise to Facilitate a Sociological Perspective.” Teaching Sociology 39(3): 227-243.

Glenn, David. 2010. "Divided Attention: In an age of classroom multitasking, scholars probe the nature of learning and memory." The Chronicle of Higher Education Retrieved 
December 3, 2012 (http://chronicle.com/article/Scholars-Turn-Their-Attention/63746/).

Grauerholz, Liz and Greg Gibson. 2006. "Articulation of Goals and Means in Sociology

Courses: What We Can Learn from Syllabi.” Teaching Sociology 34: 5- 22.

Greenblat, Cathy S. 1973. "Teaching with Simulation Games: A Review of Claims and Evidence.” Teaching Sociology 1(1): 62-83.

Harlow, Roxanna. 2009. "Innovations in Teaching Race and Class Inequality: Bittersweet Candy and the Vanishing Dollar.” Teaching Sociology 37: 194-204.

Hay, L. E. 2000. "Educating the New Generation.” The Social Administrator 57(54) 6-10.

Howe, Neil and William Strauss. 2000. Millennials Rising: The Next Great Generation. New York: Vintage Books.

Howe, Neil and William Strauss. 2003. Millennials Go To College: Strategies for a New Generation on Campus. American Association of Collegiate Registrars.

Huber, Joan and William H. Form. 1973. Income and Ideology. New York: Free Press. Humphrey, Doris J. 1970. "Simulation Review." Simulation and Games 449-456.

Irby-Shasanmi, Amy, Kathleen C. Oberlin, and Tiffani N. Saunders. 2012. "Teaching with Movement: Using the Healthy Privilege Activity to Physically Demonstrate Disparities in Society." Teaching Sociology 40(2): 123-141.

Jackson, M.W. 1979. “An Antipodean Evaluation of Simulation in Teaching." Simulation \& Gaming 10(2): 99-137.

Kaiser Family Foundation. 2005. "Generation M: Media in the lives of 8-18 year-olds." Retrieved from http://www.kff.org/entmedia/entmedia030905pkg.cfm

Kaleem, Jaweed. 2014. "One-Third of Millennials Who Left Their Religion Did It Because Of Anti-Gay Policies: Survey.” The Huffington Post Religion. Retrieved April 14, 2014 
(http://www.huffingtonpost.com/2014/02/26/millennials-gay-unaffiliated-churchreligion_n_4856094.html).

Kayes, D. Christopher. 2002. "Experiential Learning and Its Critics: Preserving the Role of Experience in Management Learning and Education." Academy of Management Learning and Education. 1(2): 137-149.

Keith, Bruce and Morten G. Ender. 2004. "The Sociological Core: Conceptual Patterns and Idiosyncrasies in the Structure and Content of Introductory Sociology Textbooks, 19402000.” Teaching Sociology. 32(1): 19-36.

Koenig, Anne M., Alice H. Eagly, Abigail A. Mitchell, and Tiina Ristikari. 2011. "Are Leader Stereotypes Masculine? A Meta-Analysis of Three Research Paradigms. Psychological Bulletin. 137(4): 616-642.

Kolb, David. A., Richard E. Boyatzis and Charalampos Mainemelis, 2001. Experiential learning theory: Previous research and new directions. In R. J. Sternberg \& L. Zhang (Eds.), Perspectives on thinking, learning, and cognitive styles. The educational psychology series (pp. 227-247). Mahwah, NJ: Lawrence Erlbaum Associates, Inc.

Kolb, David A. 1984. Experiential Learning: Experience as the source of learning and development. New Jersey: Prentice-Hall.

Lean, Jonathan, Jonathan Moizer, Michael Towler, and Caroline Abbey. 2006.

"Simulations and games: Use and barriers in higher education." Active Learning in Higher Education 7(3): 227-242.

Lewis, Linda H. and Carol J. Williams. 1994. "Experiential Learning: Past and Present.” New Directions for Adult and Continuing Education. 62: 5-16. 
Leyden, Peter, Ruy Teixeira, and Eric H. Greenberg. 2007. "The Progressive Politics of the Millennial Generation: The Emerging Evidence on Why the Younger Generation is Boosting Progressive Prospects for the Early $21^{\text {st }}$ Century.” Retrieved from http://ndnnewpol.civicactions.net/sites/ndn-newpol.civicactions.net/files/NPI-Millennials-Final.pdf

Magid Associates. 2006. "The Politics of the Millennial Generation.” Retrieved from http://www.newpolitics.net/files/MillennialGenerationPolitics.pdf

Mann, Sandi. 2009. "Why do 60\% of students find their lectures boring?" The Guardian. Retrieved December 3, 2012 (http://www.guardian.co.uk/education/2009/may/12/university-teaching).

McCammon, Lucy. 1999. "Introducing Social Stratification and Inequality: An Active Learning Technique.” Teaching Sociology 27(1): 44-54.

McNeely Ben. 2005. “Using Technology as a Learning Tool, Not Just the Cool New Thing” In Educating the Net Generation. ed. Diana G. Oblinger and James L. Oblinger, 4.1-4.10. Washington DC: EDUCAUSE.

Neuman, Scott. 2014. “Millennials “Talk to God,' But Fewer Rely on Religion, Survey Finds.” NPR. Retrieved April 14, 2014 (http://www.npr.org/blogs/thetwoway/2014/04/11/301969264/millennials-talk-to-god-but-fewer-rely-on-religion-surveyfinds).

Ng, Eddy S., Sean T. Lyons, and Linda Schweitzer. 2012. Managing the New Workforce: International Perspectives on the Millennial Generation. Northampton: Edward Elgar Publishing, Inc.

Nichols, Laura, Joshua Berry, and Demetra Klaogrides. 2004. “Hop On The Bus: Driving Stratification Concepts Home.” Teaching Sociology 32: 312- 221. 
Nikkel, Stan R. 1976. "Review Essay: A Review of Urban Instructional Simulations.” Simulation \& Gaming 7(1): 97-106.

Oblinger, Diana G., and James L. Oblinger, eds. 2005. Educating the Net Generation. Washington, D.C.: EDUCAUSE.

Oblinger, Diana G., and Paul Hagner. 2005. Seminar on educating the Net Generation. Presented at EDUCAUSE, Tempe, AZ, August. Retrieved from http://www.educause.edu/section_params/conf/esem052/OneDayv2-HO.ppt\#3.

Oser, K. 2005. "Kids cram more hours in media day.” Advertising Age. 76 (46): 31.

Persell, Caroline Hodges, Kathryn M. Pfeiffer and Ali Syed. 2008. "How Sociological Leaders Teach: Some Key Principles.” Teaching Sociology 36: 106-124.

Pew Research Center. 2006. “Once Again, the Future Ain’t What It Used to Be.” Retrieved from http://pewresearch.org/assets/social/pdf/BetterOff.pdf

Pew Research Center. 2007. "Report: A Portrait of Generation Next.” Retrieved from http://peoplepress.org/reports/pdf/300.pdf

Prensky, Marc. 2006. Don't bother me Mom-I'm learning. Minneapolis: Paragon House Publishers.

Reynolds, L., E. Bush Campbell, and R. Geist.. 2008. “The Gen Y Imperative.” Communication World. 25(2): 19-22.

Simulation Training Systems. 2013. "Learning through Experience Simulation Training Systems: Star Power.” Retrieved from http://www.stsintl.com/schoolscharities/star_power.html.

Shirts, R. Gary. 1993. Starpower Director's Instructions. Del Mar, CA: Simulation Training Systems. 
Smith, Tom W., Peter V. Marsden, Michael Hout and Jibum Kim. 2013. General Social Surveys, 1972-2012. [machine-readable data file]. Principal Investigator, Tom W. Smith; CoPrincipal Investigators, Peter V. Marsden and Michael Hout, NORC ed. Chicago: National Opinion Research Center, producer, 2005; Storrs, CT: The Roper Center for Public Opinion Research, University of Connecticut, distributor. 1 data file $(55,087$ logical records) and 1 codebook (3,610 pp).

Sweet, Stephen and Kimberly M. Baker. 2011. "Who Has the Advantage in My Intended Career?: Engaging Students in the Identification of Gender and Racial Inequalities.” Teaching Sociology 39(1): 1- 15.

Tamminga, H. L. 1977. "Moral Education Through Gaming-Simulation in Sociology. Teaching Sociology. 4: 251-270.

Tapscott, Don. 2009. Grown Up Digital. New York: McGraw Hill.

Thornton, Arland, and L. Young-DeMarco. 2001. "Four Decades of Trends in Attitudes Toward Family Issues in the United States: The 1960s Through 1990s.” Journal of Marriage and the Family. 63(4): 1009-1037.

Touzard, Giselle. 2009. "Shaped Goals: Teaching Undergraduates the Effects of Social Stratification on the Formation of Goals.” Teaching Sociology 37: 205-211.

Towns, Eleni. 2011. "How 9/11 Shaped the Millennial Generation." Center for American Progress. Retrieved April 14, 2014 (http://www.americanprogress.org/issues/religion/news/2011/09/08/10363/the-911generation/).

Twenge, Jean M. 1997. “Changes in Masculine and Feminine Traits Over Time: A MetaAnalysis." Sex Roles. 36: 305-325. 
Twenge, Jean M. and W. Keith Campbell. 2011. "Age and Birth Cohort Differences in SelfEsteem: A Cross- Temporal Meta-Analysis." Personality and Social Psychology Review. 5(4): 321-344.

Twenge, Jean M., W. Keith Campbell, and Elise C. Freeman. 2012. "Generational Differences in Young Adults' Life Goals, Concern for Others, and Civic Orientation, 1966-2009.” Journal of Personality and Social Psychology. 102(5): 1045-1062.

United Nations Population Fund. N.d. "Giving Special Attention to Girls and Adolescents." United Nations Population Fund. Retrieved April 14, 2014 (http://web.unfpa.org/gender/girls.htm).

Vince, Russ. 1998. “Behind and Beyond Kolb’s Learning Cycle.” Journal of Management Education. 22(3): 304-319.

Wessex Simulations. N.d. "Star Power: Management Training Games, Simulations \& Activities.” Retrieved from http://www.wessexsimulations.co.uk/star-power-pr16540.html

Wilson, Maureen E. 2004. “Teaching, Learning, and Millennial Students.” New Directions for Student Services. 106: 59-71. 


\section{Social Structure and Stratification}

How important do you believe each of the following is for getting ahead in life?

\begin{tabular}{|c|c|c|c|c|c|}
\hline & $\begin{array}{c}\text { Essential } \\
5\end{array}$ & $\begin{array}{c}\text { Very } \\
\text { Important } \\
4\end{array}$ & $\begin{array}{c}\text { Fairly } \\
\text { Important } \\
3\end{array}$ & $\begin{array}{c}\text { Not Very } \\
\text { Important } \\
2\end{array}$ & $\begin{array}{c}\text { Not } \\
\text { Important } \\
\text { at All } \\
1\end{array}$ \\
\hline $\begin{array}{l}\text { 1.Coming from a wealthy } \\
\text { family }\end{array}$ & & & & & \\
\hline $\begin{array}{l}\text { 2.Having well educated } \\
\text { parents }\end{array}$ & & & & & \\
\hline $\begin{array}{l}\text { 3.Having a good education } \\
\text { yourself }\end{array}$ & & & & & \\
\hline 4.Ambition & & & & & \\
\hline 5.Natural ability & & & & & \\
\hline 6.Hard work & & & & & \\
\hline 7.Knowing the right people & & & & & \\
\hline 8.Having political connections & & & & & \\
\hline 9.A person's race & & & & & \\
\hline 10.A person's religion & & & & & \\
\hline $\begin{array}{l}\text { 11. The part of the country a } \\
\text { person comes from }\end{array}$ & & & & & \\
\hline $\begin{array}{l}\text { 12.Being born a man or a } \\
\text { woman }\end{array}$ & & & & & \\
\hline 13.A person's political beliefs & & & & & \\
\hline
\end{tabular}

Please indicate to what extent you agree or disagree with the following statements and put that number in the blank provided.

$$
\begin{aligned}
& 1=\text { Strongly Disagree } \\
& 2=\text { Disagree } \\
& 3=\text { Neither agree nor disagree } \\
& 4=\text { Agree } \\
& 5=\text { Strongly agree }
\end{aligned}
$$

14. The way things are in America, people like me and my family have a good chance of improving our standard of living 
15. People would not want to take extra responsibility at work unless they were paid extra for it.

16. Workers would not bother to get skills and qualifications unless they were paid extra for having them.

17. No one would study for years to become a lawyer or a doctor unless they expected to earn a lot more than ordinary workers.

18. Large differences in incomes are necessary for America's prosperity.

19. Allowing business to make good profits is the best way to improve everyone's standard of living.

20. Inequality continues to exist because ordinary people don't join together to get rid of it.

21. Differences in income in America are too large.

22. It is the responsibility of the government to reduce the differences in income between people with high incomes and those with low incomes.

23. The government should provide more chances for children from poor families to go to college.

24. The government should provide a job for everyone who wants one.

25. The government should spend less on benefits for the poor.

26. The government should provide a decent standard of living for the unemployed.

27. The government should provide everyone with a guaranteed basic income.

28. In America people get rewarded for their effort.

29. In American people get rewarded for their intelligence and skills.

30. To get all the way to the top in American today, you have to be corrupt. 
In deciding how much people ought to earn, how important should each of the following things be, in your opinion?

\begin{tabular}{|l|l|l|l|l|l|}
\hline & Essential & $\begin{array}{c}\text { Very } \\
\text { Important }\end{array}$ & $\begin{array}{c}\text { Fairly } \\
\text { Important }\end{array}$ & $\begin{array}{c}\text { Not Very } \\
\text { Important }\end{array}$ & $\begin{array}{c}\text { Important } \\
\text { at All }\end{array}$ \\
\hline $\begin{array}{l}\text { 31.How much responsibility } \\
\text { goes with the job }\end{array}$ & & & & \\
\hline $\begin{array}{l}\text { 32.The number of years spent } \\
\text { in education and training }\end{array}$ & & & & & \\
\hline $\begin{array}{l}\text { 33.Whether the job requires } \\
\text { supervising others }\end{array}$ & & & & & \\
\hline $\begin{array}{l}\text { 34.What is needed to support } \\
\text { a family }\end{array}$ & & & & & \\
\hline $\begin{array}{l}\text { 35.Whether the person has } \\
\text { children to support }\end{array}$ & & & & & \\
\hline $\begin{array}{l}\text { 36.How well he or she does } \\
\text { the job }\end{array}$ & & & & & \\
\hline $\begin{array}{l}\text { 37.How hard he or she works } \\
\text { at the job }\end{array}$ & & & & & \\
\hline
\end{tabular}

38. Is it just or unjust- right or wrong- that people with higher incomes can buy better health care than people with lower incomes?

Very just, definitely right

Somewhat just, right

Neither just nor unjust, mixed feelings

Somewhat unjust, wrong

Very unjust, definitely wrong

39. Is it just or unjust- right or wrong- that people with higher incomes can buy better education for their children than people with lower incomes?

Very just, definitely right

Somewhat just, right

Neither just nor unjust, mixed feelings

Somewhat unjust, wrong

Very unjust, definitely wrong 
40. Some people earn a lot of money while others do not earn very much at all. In order to get people to work hard, do you think large differences in pay are...
Absolutely necessary
Probably necessary
Probably not necessary
Definitely not necessary

In all countries, there are difference or conflicts between different social groups. Please indicate how much conflict you believe there is in American between the following groups. For all questions 1 represents There are no conflicts; 2 Not Very Strong Conflicts; 3 Strong Conflicts; 4 Very Strong Conflicts.

41. Poor and rich people.

$1 \quad 2 \quad 3 \quad 4$

42. Working and middle class.

$\begin{array}{llll}1 & 2 & 3 & 4\end{array}$

43. Unemployed and people with jobs.
1
2
3

4

44. Management and workers.

$\begin{array}{llll}1 & 2 & 3 & 4\end{array}$

45. Farmers and city people.

$\begin{array}{llll}1 & 2 & 3 & 4\end{array}$

46. People at the top of society and people at the bottom.
1
2
3
4

47. Young people and older people.
1
2
3
4

The following diagrams represent types of societies. Please read the descriptions and look at the diagram and answer the questions below.

Type A: A small elite at the top, very few people in the middle and the great mass of people at the bottom.

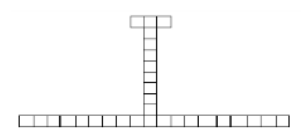

Type B: A society like a pyramid with a small elite at the top, more people in the middle, and most at the bottom.

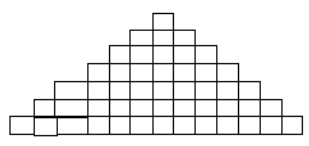


Type C: A pyramid except that just a few people are at the very bottom.

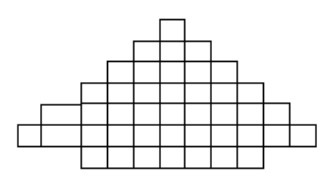

Type D: A society with most people in the middle.

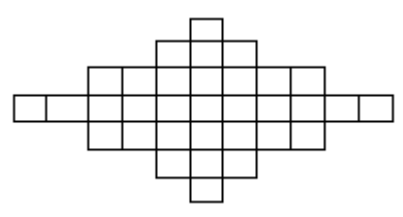

Type E: Most people near the top, and only a few near the bottom.

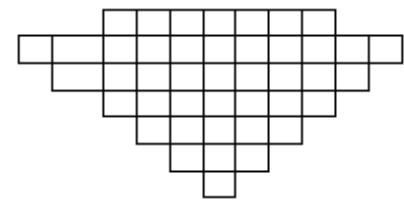

48. First, what type of society is America today - which diagram comes closest?
A
B
$\mathrm{C}$
D
$\mathrm{E}$

49. What do you think America ought to be like - which would you prefer?

A B

$\mathrm{C}$

D

$\mathrm{E}$

50. I began playing the Star Power simulation as a Square Triangle

Circle

51. I ended playing the Star Power simulation as a

Square

Triangle

Circle

Don't Remember

Did Not Participate

52. How worthwhile do you think Star Power was?

Very Worthwhile

Somewhat Worthwhile

A Little Worthwhile

Not at All Worthwhile

Gender: $\quad$ Male $\quad$ Female

Year: $\quad$ First-Year Sophomore Sunior

The description that most closely matches the neighborhood where you grew up is Urban

Suburban

Rural

Major: 


\section{Star Power Simulation Reflection Paper (30 points)}

\section{Due Date: May 2}

PART A: To begin this assignment, fully summarize and describe (giving examples and specific details) your experience in Star Power. Describe your initial thoughts and reactions as well as the activities that you were asked to perform. Please identify which simulation day/time you attended. Assume that I, as the reader, was not present at the simulation. This portion should take about 2-3 pages for the simulation description. Focus on how the different groups acted, who did what to whom, how the groups were formed, and when/how the simulation ended.

PART B: Analyze what you have learned from the simulation. In your analysis, identify and define at least 3 different class concepts (from social interaction, social structure, deviance, stratification, inequality, poverty, discrimination, etc.) that you can relate to the simulation experience. You may use any class concept from social interaction through the last day of class. After defining the concept, give concrete and specific examples of how the simulation illustrated the concept. Finally, discuss what you thought about the simulation as a learning tool. What did you personally learn about social interaction, social structure, deviance, social power, inequality, status symbols, status, roles, and inequality? Do you recommend that I use Star Power next semester? Please give examples of why or why not. Again, please give specific examples to support your opinion. If completed with sufficient detail, this section should take you at least 2 pages. 
Table 3.1:

Worthwhileness by Start Shape

How worthwhile do you think Star

$\begin{array}{ccc}\text { Circle } & \begin{array}{c}\text { Start Shape (\%) } \\ \text { Triangle }\end{array} & \begin{array}{c}\text { Square } \\ \text { (Most Points) }\end{array} \\ \begin{array}{c}\text { (Least Points) } \\ \mathbf{n}=\mathbf{4 3}\end{array} & \mathbf{n = 3 2} & \mathbf{n = 3 2}\end{array}$

Power was?

Not at all worthwhile

A little worthwhile

0.0

0.0

0.0

Somewhat worthwhile

9.3

0.0

3.1

Very worthwhile

27.9

37.5

28.1

62.8

62.5

68.8

$\chi^{2}=4.417 ; \mathrm{p}=.352$

Table 3.2:

Worthwhileness by Finish Shape

\begin{tabular}{lccc}
\hline & $\begin{array}{c}\text { Circle } \\
\text { (Least Points) } \\
\mathbf{n = 3 0}\end{array}$ & $\begin{array}{c}\text { Finish Shape (\%) } \\
\text { Triangle }\end{array}$ & $\begin{array}{c}\text { Square } \\
\text { (Most Points) } \\
\mathbf{n = 3 8}\end{array}$ \\
How worthwhile do you think Star & & & \\
Power was? & 0.0 & 0.0 & 0.0 \\
$\quad$ Not at all worthwhile & 10.0 & 2.6 & 2.6 \\
A little worthwhile & 23.3 & 35.9 & 31.6 \\
Somewhat worthwhile & 66.7 & 61.5 & 65.8 \\
$\quad$ Very worthwhile & & & \\
$\chi^{2=3.495 ; p=.479}$ & & & \\
\hline
\end{tabular}

How worthwhile do you think Star

Table 3.3:

Worthwhileness by Gender

\begin{tabular}{lcc}
\hline & $\begin{array}{c}\text { Gender (\%) } \\
\text { Female } \\
\text { How0 worthwhile do you think Star }\end{array}$ & $\begin{array}{c}\text { Male } \\
\mathbf{n = 4 0}\end{array}$ \\
Power was? & & \\
$\quad$ Not at all worthwhile & 0.0 & 0.0 \\
A little worthwhile & 7.1 & 0.0 \\
Somewhat worthwhile & 32.9 & 32.5 \\
Very worthwhile & 60.0 & 67.5 \\
$\chi^{2=3.086 ;} \mathrm{p}=.214$ & & \\
\hline
\end{tabular}


Table 3.4:

Worthwhileness by Class Standing

\begin{tabular}{lcc}
\hline & $\begin{array}{c}\text { Class Standing (\%) } \\
\text { Sirst Years }\end{array}$ & $\begin{array}{c}\text { Sophomore, } \\
\text { Juniors, Seniors } \\
\mathbf{n = 4 1}\end{array}$ \\
How worthwhile do you think Star & $\mathbf{n = 7 0}$ & \\
Power was? & & 0.0 \\
$\quad$ Not at all worthwhile & 0.0 & 4.9 \\
A little worthwhile & 4.3 & 26.8 \\
Somewhat worthwhile & 36.2 & 68.3 \\
Very worthwhile & 59.4 & \\
$\chi^{2=1.033 ; p=.596}$ & & \\
\hline
\end{tabular}




\section{Appendix D}

$\underline{\text { List and Count of Terms Identified in Reflection Papers }}$

Inequality/Social Inequality

Stratification/Social Stratification

Social Structure

Ascribed status

Status Symbol

Achieved Status

Status

Deviance

Social Interaction

Discrimination

Social Roles

Socialization

Social Comparison

Power

Resocialization

Master Status

Group(s)

Social Class

Poverty

Prestige

Reflected Appraisals

Conflict Theory

Thomas Theorem

Self

Labeling Theory

The Chess Game

Wealth

Aggregate Groups

Symbols

Income

Role Strain

Privilege

Secondary Groups

Status Inconsistency

Esteem

Primary Groups

Rebellion

Caste System

Conformity

Strain Theory

Roles

Ethnocentrism

Symbolic Interaction
Society

Class System

Pro-Social Norms

Class Welfare

Life Chances

Class Analysis

Material Culture

Role Conflict

Social Background

Sanction

Social Mobility

Norms

Bureaucracy

Social Hierarchy

Norm or Reciprocity

Authority

Norm of Social Responsibility

Neutralization

Subculture

Total Institution

Social Control

Counterculture 